\title{
Regeneration of Empire: \\ Agrarian Vision and Philanthropic Colonisation in \\ H. Rider Haggard's Novels
}

By

Sarah M. Clark

A thesis submitted to the Victoria University of Wellington in fulfilment of the requirements for the degree of Master of Arts in English Literature.

Victoria University of Wellington

2017 


\section{Clark ii}




\section{Contents}

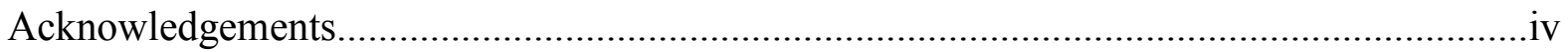

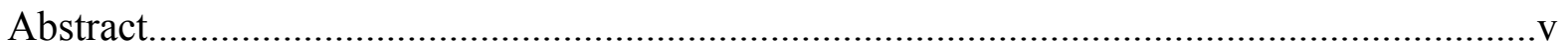

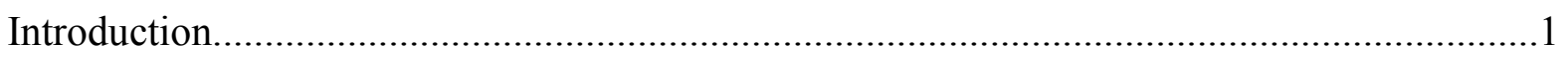

1. “"The Rider Haggard of the New Crusade:' Philanthropy and Declining Civilisations”....27

2. "Zealot, Renegade, and Reformer: Haggard's Vision for the Empire".............................54

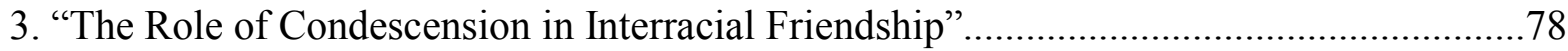

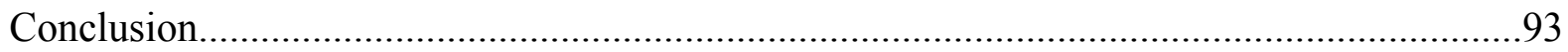

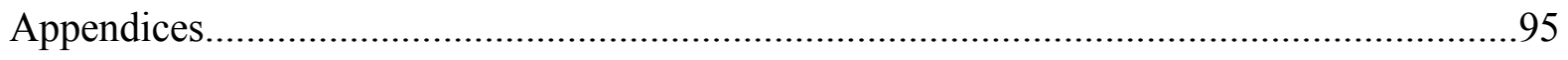

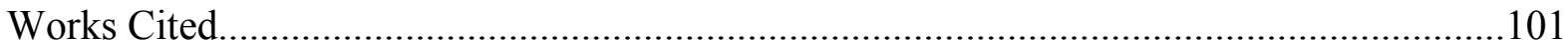


Clark iv

\section{$\underline{\text { Acknowledgements }}$}

First of all, I would like to express gratitude to my supervisors, Adam Grener and Jane

Stafford, for their guidance and thoughtful criticism during the writing of this thesis.

Secondly, I would like to thank family and friends for all their love, prayers, and support throughout the year. Special thanks to my mom, Julie, who encouraged me to leave the country for "an adventure."

Lastly, thanks to the stranger who allowed me, as a child, to discover an antique copy of King Solomon's Mines in a treasure box of unwanted books. 


\begin{abstract}
$\underline{\text { Abstract }}$
This thesis focuses on H. Rider Haggard's fictional use of philanthropic colonisation to illustrate his vision of agriculturally regenerating the British Empire. Haggard's panacea for poverty, unemployment, urban crowding, and tenuous control of imperial holdings relies on returning people back to the land. Retraining people to become farmers is the solution to all these issues; philanthropic colonisation is the mode through which his vision would come to fruition. Between 1896-1919, Haggard's depictions of Empire shift from semi-stable to precarious - a sign of his public work as an agricultural reformer influencing his fiction. I argue in this thesis that focusing on three novels, The Wizard (1896), The Ghost Kings (1908), and When the World Shook (1919), written during Haggard's work as an agricultural reformer, provides a scope in which to watch Haggard's agrarian vision develop, climax, and fade. I analyse Haggard's use of philanthropic colonisation to reflect the desired virtues of his agrarian vision as well as the charitable endeavours which expand or prolong the Empire's reach.

Chapter one, “"The Rider Haggard of the New Crusade:' Philanthropy and Declining Civilisations," traces the degradation of Haggard's hopes to regenerate the Empire through philanthropic colonisation. In The Ghost Kings, Haggard uses Rachel's charity to extend the Empire and to demonstrate the effect one individual's virtue can make in saving or destroying a civilisation; in When the World Shook, Haggard shows the depth of imperial corruption through the decay of Christian missions. Through Arbuthnot and Oro, Haggard struggles to understand the fate of the Empire; using both characters to grasp the concept of civilisation, Haggard concludes that although the Empire has serious flaws, it is ultimately worth trying to save.
\end{abstract}


Chapter two, "Zealot, Renegade, and Reformer: Haggard's Vision for the Empire," uses Gerald Monsman's idea of Haggard as a "heretic in disguise" to look at how Haggard utilises Christian missionary characters to propagate ideas of imperial regeneration. The move between zealot, renegade, and reformer character types reveals Haggard's developing sense - from the late 1890s through to 1919 — that the Empire needs to be rejuvenated.

Chapter three, "The Role of Condescension in Interracial Friendship," explores how Haggard's vision of a rebirth for the Empire is endangered by interracial friendships. Friendship strips away the prescribed roles given to both coloniser and native, allowing for something more intimate to develop. Thus, any interaction between a white and black person was socially scripted-language borrowed from philanthropic condescension. It is the act of condescension that enables interaction between a coloniser and native; only when deviating from prescribed roles does friendship become a possibility. 


\section{$\underline{\text { Introduction }}$}

\section{Preface}

As early as Allan Quatermain (1887), Rider Haggard imagines an agrarian society, ZuVendis, on which to model a rebirth of the British Empire. Haggard uses the character Allan Quatermain to explore a pre-industrial society which possesses all the aspects which England has lost as a modern civilisation. As Patrick Brantlinger notes, Haggard uses lost civilisations as a "projection and displacement of guilt for the slave trade, guilt for empire, guilt for one's own savage and shadowy impulses" (195). The placement of a lost, white civilisation within the heart of Africa speaks to Haggard's desire to shed the moral weakness and corruption which infects the Empire. To explore these tensions, Haggard endows $\mathrm{Zu}$-Vendis with elements necessary for building a self-sufficient and successful nation—elements including racial homogeneity, agrarian economics, distinct class structure, and state religion.

In terms of racial homogeneity, the $\mathrm{Zu}$-Vendi are a white and numerous people found within the interior of Africa; isolated from the outside world, Quatermain notes that the "origin of the $\mathrm{Zu}-\mathrm{Vendi}$ is lost in the mists of time" and although he speculates as to whether they are a lost Jewish tribe or of Persian descent, Quatermain concludes, "Whence they came or of what race they are no man knows" (308). Haggard places this "lost" white race in the centre of Africa to establish an obvious connection between England and $\mathrm{Zu}-\mathrm{Vendis}$.

Establishing the Zu-Vendi as an "agricultural" and "excessively warlike" people (310), Quatermain notes the economic abundance of the nation which includes gold, "a veritable El Dorado" (304), "exceedingly fertile" farmland, and coal "found in great abundance" (306). Perhaps more important than their raw economic prosperity, Quatermain looks favourably upon their class structure which is "purely agricultural in its habits, and divided into great classes as in civilized countries" (307). The classes include territorial nobility, a merchant 
and military middle class, but most importantly, a "well-to-do" peasant class who "live upon the lands of the lords, from whom they hold under a species of feudal tenure" (307). This fantasy of "well-to-do" peasants renting land from a feudal lord reflects Haggard own experience as a landowner; due to the agricultural crisis of the 1880s, many of Haggard's tenant farmers were forced to quit and find employment in cities. As to religion, which Haggard views as necessary for building a successful empire, Quatermain notes that the $\mathrm{Zu}$ Vendi's sun worship has "its roots through every institution and custom" and that "the entire social system of $\mathrm{Zu}-\mathrm{V}$ endis" is centred around its religion (313). For Haggard, state religion and its faithful adherents are essential to forming a powerful civilisation; religion is the foundation of building a successful empire. All of these racial, economic, social, and religious elements compose Haggard's ideal nation.

$\mathrm{Zu}$-Vendis is an intriguing example of Haggard's fiction foreshadowing his future public work as an agricultural reformer and his agrarian vision for the Empire. Although he had limited experience in farming, Haggard did not fully delve into agriculture until 1898, eleven years after writing Allan Quatermain, and Haggard did not develop a coherent solution to combat agricultural and imperial decline until his 1905 report, The Land and the Poor. Zu-Vendis stands as an important link between his fiction and nonfiction; it also provides an insight into Haggard's beliefs and concerns of Empire. Angelia Poon writes, "In the perfect, self-sustaining and isolated colony-nation, the English so preserved with the help of the genetically strong and primitive $\mathrm{Zu}-\mathrm{Vendis}$ can continue on an evolutionary path separate from and independent of the main racial stock in the enervated mother country" (145). Poon's interpretation of Zu-Vendis as an English preservation colony complements this thesis' focus on Haggard's agrarian vision for the Empire. First of all, Haggard's concern is for the continuity of the English people and civilisation; thus, he is ever alert to threats which could weaken it. By 1896, Haggard identified agricultural decline as the main source 
of imperial decay, and in order to reverse this decline, he proposed to resettle poor, unemployed labourers onto farmland throughout the dominions.

Interestingly, Haggard's proposed scheme includes a partnership between government and charitable organisations - a blend of government money and charitable management which was termed philanthropic colonisation. The synthesis of government and philanthropic forces provided the framework for Haggard's agrarian vision of regenerating the Empire. This thesis uses the lens of philanthropic colonisation to interpret Haggard's fiction in light of his nonfiction and to explore the tension between his roles of imperial servant and agricultural reformer, as one demands loyalty to the status-quo and the other requires radical change. I argue in this thesis that focusing on three novels, The Wizard (1896), The Ghost Kings (1908), and When the World Shook (1919), written concurrently with Haggard's work as an agricultural reformer, provides a scope within to watch his agrarian vision develop, climax, and fade. I analyse his use of philanthropic colonisation to reflect the desired virtues of his agrarian vision as well as the charitable endeavours which expand or prolong the Empire's reach.

\section{Overview of Haggard's Life}

"Novelist, Farmer, and Social Worker"- these three seemingly contradictory roles title the opening to Henry Rider Haggard's obituary in The Times ("Sir Rider Haggard"). By the time of his death on 14 May 1925, Haggard had accomplished an astonishing amount of work: 56 novels, 10 nonfiction books, and over 170 articles and letters in periodicals and journals such as The Illustrated, the Times, and the Gentleman's Magazine. Coupled with his writing, Haggard also served the Empire through a Royal Commission to assess Salvation Army Labour Camps as part of an unemployed labourers resettlement effort (1905), as a member of the Commission of Erosion and Afforestation (1906-11), and finally, through a Royal 
Commission (1911-1914) to visit and report on Dominions including Australia, New Zealand, South Africa, and Canada (Cohen 255). In the midst of a journey between Fiji and Hawaii, Haggard celebrated his sixtieth birthday (22 June 1916) alone and depressed at the thought of entering "upon old age" (Higgins, The Private Diaries 67). He writes in a diary: My work, for the most part, lies behind me, rather poor stuff too-yet I will say this: I have worked. My talent may be of copper not of gold-how can I judge of my own abilities? - but I have put it to the best use I could. My opportunities have not been many, and for the most part I have made them for myself; the book writing, the agricultural research business, the public work for instance. (Higgins, The Private Diaries 67)

He views his opportunities and successes as self-made; self-doubt haunts assessments of his talent and triumphs — perhaps a residual carry-over from his decidedly failed youth.

Born 22 June 1856, Haggard was the eighth of ten children born to William Meybohm Rider Haggard and Ella Doveton Haggard. Called "Rider" by his family, he inherited his mother's writing ability as she wrote and published poetry. As a sickly child, the sixth of seven sons, and viewed as "incorrigibly stupid" by his father, Haggard received a lesser education than his older brothers (Ellis 24). While his brothers attended private schools and were taught by tutors, he attended Ipswich Grammar School. He recalls his "reputation for stupidity" as stemming from keeping his "very imaginative ... thoughts to myself" (qtd. in Higgins, Rider Haggard 3). Failure haunted his early years- he failed to pass the army entrance exam and never sat for the British Foreign Office exam for which he studied. Haggard's father was desperate to settle his love-struck, nineteen-year-old son in a career before his "inappropriate desire" to marry a woman named Lily Jackson ruined his prospects. Thus he secured Haggard an unpaid position as an assistant to Sir Henry Bulwer, LieutenantGovernor of the Colony of Natal (15). It was during these four years that Haggard discovered 
his three passions. He dabbled in ostrich farming, interacted with Zulus and wrote observations on some of their customs and rituals, and gained his first paid position as English Clerk to the Colonial Secretary's Office (28). However, these three passionsfarming, writing, and serving the Empire-were not lucrative enough to support his expected lifestyle, so he married an heiress, Louisa Margitson. Her estate assured Haggard's position within the landed gentry, and yet this was not enough to ensure the financial security to which he aspired. Thus, he half-heartedly studied law while also writing his first nonfiction book, Cetywayo and His White Neighbors.

Despite the financial failure of this and two other works of fiction, Haggard's fortune changed when he accepted his brother's challenge to write an adventure story better than Treasure Island. Within six weeks, Haggard had written King Solomon's Mines (1885), a novel which garnered instant fame and money for his growing family of three daughters and one son. Haggard followed this with the bestseller She in 1886. These two novels cemented his popularity as a romance novelist and enabled him to pursue his other passions of farming and serving the Empire. He became a "gentleman farmer," an enthusiast whose hobby was never lucrative and one which he ultimately was forced to abandon in later years when his finances decreased. In 1895, Haggard unsuccessfully ran for parliament as the Unionist and Agricultural candidate, a conservative role for which he admitted himself unsuited: "As a party man I am the most miserable failure .... A dangerous and undesirable individual who, refusing to swallow the shibboleth of his tribe with shut eyes, actually dared to think for himself and to possess that hateful thing, a "cross-bench mind"” (qtd. in Cohen 268-9). Political ambition set aside, Haggard focused his attention on agriculture reform, a topic on which he became a well-known expert. Between his agricultural and public interests, he wrote an average of two novels per year. As the years progressed, he viewed his writing as secondary to his social work; in 1915, Haggard wrote, "Oh, I grow weary of story-telling and 
could it be managed, would devote the days that remain to the problems of the Land, that greatest of all Causes, and to the service of my Country. But few of us can do exactly what we wish" (qtd. in Higgins, Rider Haggard 222). This weariness never slowed his writing, indeed, when he died, he left behind three complete manuscripts which were posthumously published. His sentiments reveal a man burdened with writing romances in order to fund what he considered a greater "service" — a service for which he received a knighthood in 1912. Perhaps Haggard would have read with satisfaction his obituary in The Times which focuses equally on his writing and public service. After all, his legacy as a writer is incontrovertibly bound to interpreting the Empire which he served. ${ }^{1}$

\section{Philanthropic Colonisation: Historical and Social Context}

As an imperial romance novelist, Haggard wrote superbly within this genre. Plot devices such as love triangles, treasure hunts far from England, and recycled characters seem to reoccur throughout his novels, yet he writes characters that do not follow their expected stock counterparts. Through his 56 novels, one can see how Haggard uses the romance genre to explore and develop his theological and personal philosophy as well as his thoughts on Empire. Perhaps it's not surprising that Haggard's novels are populated with virile Englishmen forging into non-English territories who, while carrying with them British values and virtues, encounter civilisations against which they compare their own. Haggard's experiences serving the Empire and his literary life merge in his novels and give him a venue in which he can work out personal convictions of Empire. Two minor themes that perpetually appear through his novels are charity and colonisation. Charity appears in forms such as Christian missions or explorers providing medical care. The reasons or motivations for

\footnotetext{
${ }^{1}$ Haggard's brothers and sisters also actively served the Empire in a variety of roles. See Victoria Manthorpe's Children of the Empire: the Victorian Haggards.
} 
charity cannot be divorced from colonisation, and these points of interaction create the term philanthropic colonisation. Approaching Haggard's novels through the lens of philanthropic colonisation reveals the ways in which the novel became a venue for exploring the tensions, contradictions, and burdens of the Empire.

To better grasp the lens of philanthropic colonisation, a bit of context and definition are necessary. Philanthropic colonisation, as a term, is first used in connection to Haggard in 1905 upon his visit to Salvation Army labour camps on behalf of the Colonial office. A San Francisco Call article reads,

H. Rider Haggard, the popular writer of romantic fiction, has recently presented to the British Parliament his report upon the work entrusted to him by the Colonial Office. That duty was to study the Salvation Army colonies in the United States and at Hadleigh, England. The information was wanted to aid in the planning of a scheme a national land settlement — the projected transfer of urban populations of the United Kingdom to the difference parts of the British Empire. The report has enough of encouragement to philanthropic workers to make the romance of reality more attractive than fiction. Some day Mr. Haggard may write of marvels done in colonization a true story which will be of more thrilling interest to the public than any of the tales of imagination with which he has delighted readers. ("Philanthropic

\section{Colonization")}

The unnamed journalist mentions Haggard's literary success and how, upon the success of this philanthropic effort, perhaps Haggard will write romances of reality. This idea of philanthropy producing a romantic reality points to the power imbued by late-Victorians by charity. Charity is a valued virtue and form of soft power useful in shaping native peoples and lower socioeconomic classes into ideal, imperial citizens. A philanthropic upper class 
was imperative to propagating this virtuous vision of Empire. Monied people, like Haggard, were crucially needed by the Empire at the turn of the century to carry out imperial work and interests without remuneration. Thus philanthropic colonisation arose from Britain's rich history of social charity and was married to colonial expansion. In this thesis, three aspects of philanthropic colonisation are explored: philanthropy as an imperial virtue, transmission of imperial knowledge through Christian charity, and condescension in interracial relationships.

At the end of the nineteenth century, two pressing issues faced the Empire: 1. an increase of impoverished and unwaged labourers living in urban settings like London; 2. tenuous control over imperial dominions that were increasingly seeking more independence. Haggard and his contemporaries in the late-Victorian and Edwardian periods sought "to preserve, to maintain, to solidify, to perpetuate" the Empire which threatened to unravel under pressure from these and other social concerns (Gorman 3). To address the rapid increase of poverty associated with increased urbanisation and industrialisation, a movement formed to unify individual and local charitable efforts into a national solution. The Charity Organization Society (COS) movement spanned approximately 1869-1893, and marked an evolution in philanthropic tendencies which signalled the beginning of modern social welfare. The COS movement introduced scientific processes to determine and track the applicants to charity; methods such as investigation, registration, and supervision were utilised by amateur investigators called "social workers." According to Dr. John E. Hansan, a prominent social worker and founder of The Social Welfare History Project, the COS movement's main focus was "to employ a scientific approach to cope with the expanding problems of urban dependency, the proliferation of private philanthropies and growing evidence that some individuals and families had learned to 'game' the system by successfully appealing to multiple organizations for help" (Hansan). In essence, the COS movement 
followed its charitable predecessors by adopting the moral reform emphasis popular amongst Christian mission societies. ${ }^{2}$

Philanthropy during the nineteenth century centred on three elements: moral reform, social reform, and relief (O’Brien 3). Haggard's work focused on social reform, specifically agricultural reforms. As a child, Haggard witnessed the final years of the English agricultural boom; by the 1870 s, the industry suffered a massive decline due to factors such as consecutive years of bad crops, surges in animal diseases, and heightened competition from the United States. Within ten years, one million rural workers and their families had left the countryside to seek employment in cities (Ellis 154). Haggard's interest in this issue arose from his own attempt at farming on his estate in Ditchingham. Between 1886-1899, he wrote a number of letters to The Times on the topic of agriculture, challenges ranging from tenants unable to afford leasing land, ${ }^{3}$ to an impending "agricultural crisis" which threatened the stability of landowners, farmers, and labourers, ${ }^{4}$ to the shrinking population willing to labour on farms (Haggard blamed education and insufficient housing for making agriculture an unpalatable occupation to the youth). ${ }^{5}$ In 1899 , Haggard's experiences with and observations on farming were published in his second nonfiction book entitled A Farmer's Year: Being His Commonplace Book for 1898. A popular work when first published, A Farmer's Year is now recognised as an important historical document in understanding turn-of-the-century farming techniques. Of equal importance are the first-hand experience and connections Haggard gained through his experiment in farming. During that year, he learned from

\footnotetext{
${ }^{2}$ For a detailed analysis of the COS movement, see Lauren M .E. Goodlad's Victorian Literature and the Victorian State: Character and Governance in a Liberal Society (pp. 192237).

${ }^{3}$ See Haggard's "The Land Question” (1886).

${ }^{4}$ See Haggard's “Agriculture in Norfolk” (1895).

${ }^{5}$ See Haggard's "Shrinkage of Population in Agricultural" (1899).
} 
neighbours, tenants, and labourers the financial impossibility of surviving through farming during a depression. As Morton Cohen says, Haggard "was stunned by what he saw at first hand, by what, he was forced to conclude, was the ruinous decay of a treasured part of English life" (Cohen 163). This experience of "shock and concern" marked the beginning of a new phase in his career - that of an agricultural expert and reformer (Cohen 163).

The other issue which Haggard connected to agricultural decline was the Empire's tenuous control over dominions and territories. Like his contemporary Thomas Sedgwick, a social worker who promoted youth emigration schemes, Haggard viewed "individual citizens as imperial capital” (Gorman 27). Gorman's description of Sedgwick's views can be extended to Haggard's: "He perceived imperial issues to be extensions of domestic issues" (27). For Haggard, the solution to resolving national poverty while simultaneously fortifying imperial holdings was to send Britain's unemployed labourers to unfarmed lands. The answer to his pet concerns of agricultural and imperial decline came in the form of an imperial invitation. In January 1905, he was asked by Colonial Secretary, Alfred Lyttelton, to serve as a commissioner to inspect Salvation Army Labour Colonies which provided farm labour training to unemployed city dwellers. Lyttelton wrote, "It is thought that if on inquiry this system is found to be financially sound and to be a real benefit to the poorer classes, it might prove a useful model for some analogous system of settlement from the United Kingdom to the Colonies" (qtd. in Cohen 240). Haggard spent two months in the United States inspecting Salvation Army Labour Colonies: Fort Romie in California, Fort Amity in Colorado, and Fort Herrick in Ohio (Cohen 241). Before returning to England, he went to Canada and acquired official commitment from the government to reserve 240,000 acres of land for impoverished British settlers. Upon his return, he submitted his official report which was later published as The Poor and the Land: Report on the Salvation Army Colonies in the United States and at Hadleigh, England, with Scheme of National Land Resettlement. 
Haggard's introduction to the Salvation Army's training camps signalled an important development in his ideas on reforming agriculture, and by extension, the Empire. The details of The Poor and the Land will be explored in depth in the final section of this chapter, but, for now, the main focus will be on how Haggard's scheme changed from a government-led solution to one dependent on leadership by philanthropic organisations, such as the Salvation Army. Impressed by their organisation, Haggard additionally valued their global reputation for trustworthiness amongst the lower classes. In the introduction to The Poor and the Land, He writes, "They [the Salvation Army] enjoy to a remarkable degree the confidence of those classes that it is proposed to help; indeed countless numbers of the poor of all races throughout the world trust them entirely" (xvi). ${ }^{6}$ The Salvation Army's work was twofold: training and moulding ideal subjects for the King (both in the spiritual and national sense). ${ }^{7}$ Gorman claims that by the end of the nineteenth century, a "Platonic conception of citizenship whereby the citizen strives to attain the ideal, began to gain favour" (14). This claim resonates true when viewing Haggard's shift from governmental to philanthropic solutions-when he wrote Rural England: Being an Account of the Agricultural and Social Researches Carried Out in 1901 and 1902, he toured England to survey the state of agriculture throughout the country. His findings led him to conclude that only government assistance, specifically political assistance through tariff reform, could reverse the industry's decline; however, his suggestions were permanently tabled when the Liberals won the general election of 1906 (Burchardt 142).

\footnotetext{
${ }^{6}$ Haggard was so impressed by the Salvation Army's work that he agreed to General Booth's request to write a nonfiction book titled: Regeneration: Being an Account of the Social Work of the Salvation Army in Great Britain (1910).

${ }^{7}$ In 1910, the Salvation Army served in 56 countries, sheltered over 28,000 homeless people, ran 521 schools for children, and oversaw 157 retraining factories for the unemployed. See Michael R. Watts' The Dissenters: Volume III: The Crisis and Conscience of Nonconformity (p. 309).
} 
Although his keen observations on the state of agriculture were widely admired and acknowledged as factual, critics, mostly conservatives, saw Haggard's suggested tariff reform as a "gospel of dependence on the government" and accused him of becoming "an almost apostolic" social reformer (Ellis 163). Haggard changed tactics in The Land and the Poor, suggesting instead a blend of government, self-help, and philanthropic assistance to address the twin issues of agricultural and imperial decline. Sensitive to accusations of being a "socialist," Haggard warned critics of his scheme near the ending of his introduction to The Land and the Poor, "Every winter a clamour and a crisis with wild threats and violence, appeased for the hour by ever-increasing inroads on the rates and other public funds. Then when the next winter comes the same desperate, ominous shapes of Misery and Want, and in their hands the swords of Socialism" (xxix). Haggard was clearly distancing himself from supporting a social welfare state, and even accused the current government of appeasing and retaining control of people in poverty through public money. Haggard viewed his own solution as an "ark of refuge" which would use limited public funds, dispensed and monitored by philanthropic organisations, to train and relocate model labourers to cultivate land throughout the dominions; and, finally, after the farms had proven profitable, the labourers would repay the loan to the philanthropic organisation who would in turn make report and submit the funds back to the government. Before Haggard's tour of Australia and New Zealand in 1916, during which he hoped to secure promises of farmland for resettlement, he received a telegram from Earl Grey, apologising for critics of his mission. Grey said, "If the Empire is to continue there must be great inter-emigration between England and the Dominions. The settlement of the vacant Dominion lands with Britons will contribute to the strength and safety of the Empire" ("The Empire Problem"). The significance of this notice lies in highlighting public awareness of Haggard's mission- throughout the nation, 
and indeed the Empire, his work and scheme were known ${ }^{8}$. Thus did his vision for the rebirth of agriculture and Empire result in the term "philanthropic colonisation."

\section{Overview of Literary Scholarship on Haggard}

After his death in 1925, Haggard's reputation as a writer relegated him to obscurity with only secondary references to him within literary scholarship on contemporaries such as Rudyard Kipling. For nearly 50 years, biographers were the sole scholars to explore the importance of his life and novels. The first biography, The Cloak That I Left, was written and published by Haggard's daughter, Lilias Rider Haggard, in 1951. Three important biographies followed, each interpreting his life in subtly distinct ways: Morten Cohen's Rider Haggard: His Life and Work (1960) seeks to understand why literary critics ignore his works while famous writers such as C.S. Lewis and Graham Greene cite him as a source of inspiration (16); Peter Berresford Ellis' H. Rider Haggard: a Voice from the Infinite (1978) uses the theme of "man's ambiguous state in the universe" as a framework to interpret his life and novels (10); D.S. Higgins' Rider Haggard: the Great Storyteller (1981) focuses on explaining Haggard's obsession with death and immortality (ii). By the late 1970s, scholars began to read his novels with an emphasis on imperial discourses.

In the 1980s, Norman Etherington wrote the "first book length study of Haggard's fiction" (Rider Haggard); however, his work was not the most influential literary criticism of the decade - that credit belongs to Wendy Katz, author of Rider Haggard and the Fiction of Empire (Hultgren 646). Katz's interpretation of Haggard as an "imperial propagandist" set the overarching tone of criticism well into the early 2000s (193). Katz's premise hinges on exposing the racist and imperialist ideology which she found woven throughout all of

\footnotetext{
${ }^{8}$ See "Sir Rider Haggard’s Mission" (1916).
} 
Haggard's novels. For Katz, Haggard's romances “illustrate a total mentality, a philosophy of life, an idea of humankind completely in harmony with the imperial ideology" (4). This idea of Haggard's romances reflecting a world ordered around imperial truths and assumptions informs Katz's choice to chronologically survey a selection of Haggard's novels—Katz builds a connection between significant political incidents (such as the post-Boer War period) and the influence on Haggard's thoughts and subsequent manifestation in his romances (5). Katz uses six different facets to build a composite of him as "a man who made use of every opportunity to advance matters relating to Empire" (153). These facets are as follows: equating Haggard's "love" for farming and land to his "love" for Empire (7); asserting Haggard's choice to write within the romance genre as representative of imperial yearning to escape industrialisation (30-31); identifying the imperial hero archetype within his romances as men whose acts of service for the Empire are invested with spiritual qualities (82); connecting the theme of fatalism to his need to understand the place of Empire with the cosmos (107); claiming the way in which he mixes science and spiritualism reveals his awareness of these as imperial tools of native subjugation (129); establishing a connection between a "coherent imperial pattern" of racism within his novels and the Empire's wielding of racism as a "means of developing and maintaining power" (131-35). Katz's framework allows for insightful connections between Haggard's fiction and the Empire's propagation through fiction; however, her argument relies on broad generalisations which ignore or, at times, misinterpret the contrary textual evidence. In chapter three of this thesis, I explore her misinterpretation of white and native interactions and her misuse of the character Ishmael from The Ghost Kings as an example of civilised degradation from too close contact with Africans.

Following within the vein of Katz's criticism, critics in the 1990s began to analyse Haggard's novels through postcolonial discourses on gender and race. Critics such as Laura 
Chrisman in "The Imperial Unconscious? Representations of Imperial Discourse" and Elaine Showalter in Sexual Anarchy focus their work on reading She through a feminist lens to expose the fears of imperial masculinity (Hultgren 654). Perhaps the most influential criticism on Haggard since Katz has been Anne McClintock's Imperial Leather: Race, Gender, and Sexuality in the Colonial Contest — an audacious and enlightening reinterpretation of King Solomon's Mines. McClintock opens with a close reading of the treasure map from King Solomon's Mines - a map to diamond mines which she deciphers as representing three complementary discourses: female sexuality, economic production, and racial differences (5). By connecting his colonial service to his non-existent financial prospects as a young man, McClintock views Haggard's journey to South Africa as an attempt to restore his family fortune (240). She also postulates that the possession of the diamonds at the end of the novel by Quatermain, Good, and Curtis, reveals Haggard's class loyalties as the diamonds are given to the "landed gentry" and not the "mining capitalists" (256). Although McClintock's work focuses on a much larger array of topics than listed above, I have highlighted the aspects which intersect with my own area of research.

In 2000, Laura Chrisman again wrote on Haggard, this time highlighting the influence of British and South African politics on his romances in a book entitled Rereading the Imperial Romance: British Imperialism and South African Resistance in Haggard, Schreiner, and Plaatje (Hultgren 655). Chrisman follows up with another book called Postcolonial Contraventions: Cultural Readings of Race, Imperialism and Transnationalism in 2003 in which she engages directly with McClintock's reading of King Solomon's Mines. Chrisman contends that Haggard's writing "reveals (even as it attempts to resolve) discontinuities between imperial-metropolitan and settler-colonial interests and ideologies" and that "Haggard's non-fictional writings show him torn between the two" (46). While Chrisman grapples with Haggard's conflicting ideologies, South African critic, Lindy Stiebel, writes a 
comprehensive study called Imagining Africa: Landscape in H. Rider Haggard's African Romances in 2001. Stiebel seeks to understand how Haggard's use of landscape can provide a "historical and geographic context" while also taking "Haggard seriously as a mapper of his age's anxieties and desires" (xi-xiii). Stiebel's approach to reading Haggard as a "serious writer" vs. an "imperial hack" connotes a shift from previous critics who viewed Haggard as merely a purveyor of imperial discourse.

This shift signalled new modes of examining Haggard's novels, and critic Gerald Monsman ushered in a resurgence of interest in Haggard scholarship. Monsman's H. Rider Haggard on the Imperial Frontier: the Political \& Literary Contexts of His African Romances (2006) attempts to revitalise Haggard's modern literary reputation through contextualising biographical and historical details within nineteenth century ideologies (1). Monsman places Haggard's African romances within the context of colonial fiction, a choice questioned by subsequent critics, but one which Monsman defends by showing "how his [Haggard's] fiction reflects an agenda of imperial dissent, suggests an idealistic belief in the value of Anglo-African cultural rapport, and anticipates innovative anthropological and cultural principles" (1). Monsman depicts Haggard as a "heretic in disguise"-a man who publicly supports an imperial agenda, but who privately uses his fiction to promote subversive thoughts on race (supporting "the Zulu national consciousness") and gender (depicting “strong, passionate, and principled women”) (44-5). Monsman's reading of Haggard's novels is diametrically opposite to Katz's, and his framework enables this by removing Haggard from traditional imperial discourse and placing him in the context of colonial dissenters like Olive Schreiner. Monsman tracks recurring narrative elements in Haggard's novels, yet explores the differentiating nuances of each novel. Monsman further asserts Haggard's significance as a writer by saying he "fused the heterogeneous fields of comparative literature, religion, and anthropology to perfect the imperial adventure novel. 
This deliberate blending of motifs and themes from the other disciplines and media (may we call it protohybridization?) gave his novels more character than those of his predecessors and represented the ultimate step in the development of this genre" (236). To Monsman, Haggard's originality lies in his artistic choices to deviate from the traditions of the romance genre; infusing elements of medicine, archaeology, and philosophy elevated Haggard's romances above those of his contemporaries.

After Monsman, literary critics have focused on interdisciplinary topics within Haggard's novels, topics such as anthropology, occultism and spiritualism, ${ }^{9}$ archaeology, ${ }^{10}$ music, ${ }^{11}$ environmentalism. The past ten years has yielded an eclectic array of works: Francis O'Gorman's chapter in Victorian Literature and Finance (2007), titled "Speculative Fictions and the Fortunes of H. Rider Haggard," explores the connection between Haggard's financial risk-taking as a romance writer and the venture capitalist nature of many of his heroes; Philip Liebfried's book, Rudyard Kipling and Sir Henry Rider Haggard on Screen, Stage Radio, and Television (2008) catalogues the impact Kipling and Haggard's fiction had on early film; most recently, John Miller's chapter, “The Environmental Politics and Aesthetics of Rider Haggard's King Solomon's Mines: Capital, Mourning and Desire” in Victorian Writers and the Environment: Ecocritical Perspectives (2017), delves into Haggard's conflicting environmental politics of South Africa as both an economic resource and primal home. ${ }^{12}$ This is the point at which my own research intersects with current trends within Haggard

\footnotetext{
${ }^{9}$ See Roger Luckhurst's The Mummy's Curse: the True History of a Dark Fantasy (2012).

${ }^{10}$ See Shirley Addy's Rider Haggard and Egypt (1998).

${ }^{11}$ See Claire Mabilat's Orientalism and Representations of Music in the Nineteenth-Century British Popular Arts (2008).

${ }^{12}$ Here are a few scholars who have recently expanded discussions on imperialism in Haggard criticism: 1. Tania Zulli's Colonial Transitions (2012); 2. Nathan K. Hensley's Forms of Empire: The Poetics of Victorian Sovereignty (2016); 3. Richard Reeve's "Henry Rider Haggard's Debt to Anthony Trollope: Dr Therne and Dr Thorne" (2016).
} 
scholarship. I noted a gap in criticism connecting Haggard's fiction and nonfiction to the topic of charity or philanthropy - a theme which resonates throughout his writing and career - and chose to explore Haggard's views on philanthropy within the historical context of the COS movement.

\section{Thesis Argument}

H. Rider Haggard lived as an imperial servant, toiling to further the Empire - a behemoth social construct whose strength waxed and waned during his lifetime. Outside the requisite military power from which it was born, the Empire increasingly turned to soft forms of power to expand and hold onto its territory. One such form of soft power was a marriage of two fields, charity and colonisation, better called philanthropic colonisation. Haggard's characters inhabit a world built upon imperial truths - truths or assumptions which contribute to a system in which religion (Christianity) is used to instil British values, charity is used to bestow gifts of knowledge and technology to supplant native religions and methods of living, and condescension is used to establish unequal relationships between the British and native peoples.

Haggard's novels reflect the truths and endeavours he believed would perpetuate a thriving Empire, and expose the influence of his life-long work as an agricultural and imperial reformer. His earliest novels are populated with heroes such as Thomas Owen in The Wizard, who are products of imperial training, yet who find these truths tested in the wilderness of Africa. In these novels, the foundation of their world rests firmly in the strength of the Empire. By the turn of the century, Haggard's protagonists such as Allan Quatermain, Rachel Dove in The Ghost Kings, and Humphrey Arbuthnot in When the World Shook, feel the foundation of the Empire shake, cracks form in their mighty civilisation, a fear of its demise prompting Haggard to personally invest in the counter solution of agriculture. 
Focusing on three novels written between 1896-1919, I argue that he uses philanthropic colonisation to reflect the desired virtues of his agrarian vision as well as the charitable endeavours which expand or prolong the Empire's reach.

\section{Haggard's Vision for the Empire}

Any discussion of Haggard's views or beliefs on Empire is fraught with ambiguity and contradictions; publicly and privately, Haggard professed strong loyalty to his nation and its imperial causes, yet he also confessed misgivings about the Empire's course and, at times, hinted at personal views contrary to the Empire's vision. As Tim Murray suggests, Haggard's view on Empire was less idealism and more "imperial pragmatism." Murray writes that two core beliefs mark Haggard's views on Empire: "First, the British Empire was doomed to fall, and second, its demise would be hastened by a diminution of its finest qualities at the hands of people from trade. The hard bit for Haggard was to persuade the rest of British society that although the Empire was doomed, it was their sacred duty to hold the lantern of civilization aloft, before passing it to the Americans" (Murray 42). This "imperial pragmatism" surfaces early in Haggard's fiction and underscores the duality of his relationship to the Empire-on one hand, he believes "that every citizen should give the best that is in him to the State as a matter of public duty" (Higgins, The Private Diaries 276), and, yet, the spectre of industrialisation promises to "rob" the "patient, even minds" and "enduring bodies" of former farm labourers (A Farmer's Year ix). As his early novels indicate, Haggard's sense of duty supersedes any pessimism about the Empire's future, but his loyalty did not impede a foreboding pattern of decaying civilisations from appearing in his writings.

By the mid-1890s, Haggard started to imply that national issues such as civil unrest and poverty are connected to agricultural decline. It was not until A Farmer's Year (1898), which recounts Haggard's financially unsuccessful attempt to farm his own estate, that 
Haggard fully grasped the scale of this national disaster and began to formulate a cohesive link between agricultural and imperial decline. As Morton Cohen notes, Haggard believed the strength of the Empire relied on a "strong heart"-England's power rested on its natural resources, "upon a strong agrarian population standing behind the civil, the industrial, and the military" (166). Although he had diagnosed a source of decline, Haggard needed to conceive a reversal plan. The result of his agricultural tour of England, detailed in Rural England (1902), suggested that government intervention, through tariff reform, would be necessary to bolster farming. When this solution was politically unsuccessful and derided as "socialist," Haggard retreated from state involvement and soon discovered a model for his own vision. His visit, as a commissioner, to inspect Salvation Army Labour Colonies in 1905, inspired a new approach to correct the failing agriculture industry.

Haggard's new scheme of "national land resettlement" was detailed in The Land and the Poor (1905), a report on the successes of the Salvation Army training camps. In the introduction, he stated that the purpose of his report is to find "the example best ... to use in connection with the projected transfer of urban populations of the United Kingdom to different parts of the British Empire" (vi). It is important to note that "the projected transfer of urban populations" was the reason why Haggard was commissioned by the government to visit these camps; unlike Haggard, the government did not view this scheme as an opportunity to bolster the agriculture industry. His sole commission was to inspect the camps to assess the feasibility of copying the Salvation Army's resettlement model on a national level. What follows from the report were not merely his observations, but his well-thoughtout plan for implementing this model. Haggard's scheme was as follows: "To combine a judicious use of the Public Credit with that of what I have called the "waste forces of Benevolence,' and by means of these two levers to lift some of the mass of human misery which demonstrates itself in the great cities of civilisation to a new level of plenty and 
contentment" (ix). In essence, Haggard was suggesting the pairing of government and charity organisations to bring people out of cities and to place them onto farmland. His detailed plan involved: 1. the government providing funds to loan, with interest, to the settlers, thus enabling the poor to buy their land in payments; 2 . the use of charitable organisations, like the Salvation Army, to administer the dispersal and collection of the loans (xi). ${ }^{13}$ Haggard sold this scheme as "one of imperial investment, not of imperial charity," an important distinction for potential critics who would shrink from any form of social welfare (xiii). He also explained that philanthropic organisations, rather than private businesses, were pivotal to this plan for financial conservation (reimbursed for "out-of-pocket expenses only") and moral reasons ("servants of such Organisations in most cases are subject to a stricter master, namely, their own consciences") (xii). Aware of critics worried about losing too many of the population to resettlement, Haggard appealed to their national desire for strong soldiers by claiming “the great majority of the 'puny pigmies' spring from the towns or town-bred parents, while the 'robust and intelligent' yeoman are country born" (xix). Thus, Haggard's scheme not only resettled and retrained impoverished labourers for farming and strengthened connections with the dominions, it also guaranteed the Empire a strong military of "robust" men who were "country born." Haggard also stated that the resettlement scheme would secure Britain's future control of areas such as Rhodesia (xxii). He warned against doing nothing, and accused the current government of pacifying the poor who came in "the same desperate, ominous shapes of Misery and Want" with the "swords of Socialism" (xxix). He concluded by saying, "I hope that some day the Nation will come to understand that the true cure or palliative for these and many other troubles is to be found, not in workhouses or in

\footnotetext{
${ }^{13}$ For more information on the Salvation Army's influence in organised philanthropy, see Sebastian Conrad and Dominic Sachsenmaier's Competing Visions of World Order: Global Moments and Movements, 1880s-1930s (pp. 29-68).
} 
other State-supported institutions, but upon the land, whether it be the land of Britain or that of her immeasurable Empire" (xix-xxx). Haggard's panacea for poverty, unemployment, urban crowding, and unstable control of imperial holdings relied on returning people back to the land. ${ }^{14}$ Retraining people to become farmers was the solution to all these issues; philanthropic colonisation was the mode through which his vision would come to fruition. Through his lifetime, Haggard watched the Empire decay from within and he believed its regeneration would be through agriculture.

If one applies Haggard's agrarian vision of Empire to interpreting his novels, an interesting pattern of development occurs. Between 1896-1919, Haggard's depictions of Empire shift from semi-stable to precarious - a sign of his public work influencing his fiction. Following in the footsteps of Gerald Monsman, I "freely applied New Historicist interpretation of the interconnections among his textual personae, his own personal life and behaviour, and the cultural belief systems that both bind him and are subverted by him" (Monsman, Rider Haggard 43). Through a close reading of his agricultural nonfiction (The Poor and the Land, Rural England, A Farmer's Year), connections between his public service, personal interest in farming, and inherited fear of imperial decline can be traced in his novels. The ways in which Haggard imagines an imperial regeneration of the Empire results in the fictional use of philanthropic colonisation; examples include Christian missions, Western medical care, teaching African natives Western agricultural techniques, and condescension in interracial relationships. A selection of three novels over a twenty-threeyear period (1896-1919) allows for sufficient growth or evolution of Haggard's views and writing. The first novel to consider is The Wizard (1896), an African romance with a formulaic plot of Christianity triumphing over native religion; the second novel is The Ghost

\footnotetext{
${ }^{14}$ For an assessment on the effects of Haggard's report (The Land and the Poor), see John Field's Working Men's Bodies: Work Camps in Britain, 1880-1940 (pp. 110-13).
} 
Kings (1908), another African romance which, unusually, features a strong, female protagonist; the third novel, When the World Shook (1919), is perhaps the most original as it is Haggard's first and only science fiction novel. These three texts were selected due to their proximity to important developments in Haggard's agricultural work and nonfiction; additionally, each possesses elements of philanthropic colonisation which connect to Haggard's vision of Empire. This thesis does not explore Haggard's agrarian vision in either of his most famous novels, King Solomon's Mines or She, as both precede his public service in agriculture; by using three, non-canonical novels, one is better able to grasp the nuance and development of his relationship with the Empire.

\section{Overview of Thesis Chapters}

Chapter one, “"The Rider Haggard of the New Crusade': Philanthropy and Declining Civilisations," traces the deterioration of Haggard's hopes to regenerate the Empire through philanthropic colonisation. Between publishing The Ghost Kings (1908) and When the World Shook (1919), Haggard's agrarian vision, as laid out in The Land and the Poor (1905), gained parliamentarian supporters; however, his scheme was sidelined and eventually ignored due to World War I. Throughout many of his novels, Haggard examines the forces which contribute to a civilisation's decline; he also uses fictional civilisations as foils to contrast the Empire's virtues with their depravity. For him, philanthropy was a virtue which differentiates and elevates the British Empire from and above other civilisations. In The Ghost Kings, the heroine, Rachel, embodies Haggard's vision of an ideal citizen whose imperial virtues condemn a corrupt, rival civilisation; in contrast to the Ghost rulers, Rachel's power resides in her ability to dispense justice and goodness without the use of military force. The foundation of Rachel's power is secure as the imperial virtues she inherits are drawn from a steady civilisation, the British Empire; however, Haggard's certainty in Britain's future was 
shaken by the advent of World War I. By the time he wrote When the World Shook, his agrarian vision seemed insufficient to stave off the degradation of modern civilisation. Haggard uses protagonist Humphrey Arbuthnot and antagonist, superhuman Oro to explore the ways in which an ancient civilisation, such as the Sons of Wisdom, nearly destroyed the world in similar ways to the Empire. Additionally, Haggard's faith in British virtues declined to a fatalistic pessimism which increased his belief that the Empire had reached the decaying portion of its existence. Although he was mentally and spiritually overwhelmed by the barbarity of the war, Haggard retains hope for the Empire's future. In The Ghost Kings, Haggard uses Rachel's charity to extend the Empire and to demonstrate the effect one individual's virtue can make in saving or destroying a civilisation; in When the World Shook, Haggard shows the depth of imperial corruption through the decay of Christian missions. Through Arbuthnot and Oro, Haggard struggles to understand the fate of the Empire; using both characters to grasp the concept of civilisation, Haggard concludes that although the Empire has serious flaws, it is ultimately worth trying to save. Between these two novels, Haggard's hope to regenerate the Empire through philanthropic colonisation fades, yet he never ceases his crusade to resettle people onto farmland.

Chapter two, “Zealot, Renegade, and Reformer: Haggard's Vision for the Empire," uses Gerald Monsman's idea of Haggard as a "heretic in disguise" to look at how Haggard utilises Christian missionary characters to propagate ideas of imperial regeneration. The move between zealot, renegade, and reformer character types reveals Haggard's developing sense - from the late 1890s through to 1919 — that the Empire needs to be rejuvenated. In The Wizard (1896), Haggard portrays a Christian clergyman, Thomas Owen, who becomes a zealot for reaching a tribe both Church and Empire are uninterested in contacting. Zealots, like Owen, are crucial to Haggard's agrarian vision as their ardour can not only inspire people to return to farming and church, their actions can also provide additional lands for 
colonisation; the zealot also plays an important role in instigating Haggard's philanthropic colonisation scheme. In The Ghost Kings (1908), Haggard uses renegade John Dove's legalistic faith to expose the hypocrisy of the Church, and in turn connects the spiritual lethargy of the Empire to its potential decline. Haggard's agrarian rebirth of empire is tied to successfully refurbishing the national religion of Christianity; in order to cement the Empire's hold throughout the world, Christianity needed to become more malleable or adaptable to native customs. In When the World Shook (1919), Haggard uses Basil Bastin, a missionary bent on reforming missions' public image, to demonstrate the farcical yet noble nature of attempting a reformation through old and outdated methods. He uses Bastin as a way to explore the tension between the foolishness and nobility of attempting to reform an institution as complex as Christian missions or the Empire. For Haggard, the foolishness of his agrarian scheme is tempered by the nobility of his faith in restoring a civilisation deconstructed by the war. In the movement amongst these three characters-zealot, renegade, and reformer — one can trace Haggard's evolving perception of Christian missionaries and the roles which they might play in restoring the Empire. For Haggard, religion and civilisation are intertwined - the spiritual lethargy or decline of religion signals the impending doom of a civilisation. Thus, these characters' mission, indeed Haggard's it might be argued, is to win people to a pure and ancient faith which will foster an edenic, agrarian society.

Chapter three, "The Role of Condescension in Interracial Friendship," explores how Haggard's vision of a rebirth for the Empire is endangered by interracial friendships. If his scheme for resettling unemployed labourers or retired soldiers onto "empty" farmland is to be successful, Haggard must acknowledge the interracial tensions bound to develop when the colonisers arrive on native lands. Even more dangerous than potential fighting, though, is the possibility of friendship developing between the races. After all, friendship strips away the prescribed roles given to both coloniser and native, allowing for something more intimate to 
develop. Thus, any interaction between a white and a black person is socially scriptedlanguage borrowed from philanthropic condescension. It is the act of condescension that enables interaction between a coloniser and native; only when deviating from prescribed roles does friendship become a possibility. Through close analysis of interracial relationships in The Ghost Kings and The Wizard, one can see how the language of condescension facilitates the development of friendship; additionally, a typical structure appears in Haggard's interracial friendships in which the white character saves the native, and the native in turn dies to save the white character in the end. Unlike the master vs. student relationship portrayed between Thomas Owen and Hokosa in The Wizard, Haggard depicts the development of a sister-like friendship between Rachel Dove and Noie in The Ghost Kings. Haggard's use of interracial friendships and this recurring plot trajectory reveals not only racist imperial sentiments, but also perceived dangers to the Empire's continuity. His focus on rebuilding or rebirthing the Empire conflicts with his respect and admiration for native peoples, such as the Zulus. Through his romances, Haggard explores the tension that exists within his psyche and the social constructs which support the Empire. 


\section{Chapter One}

\section{"The Rider Haggard of the New Crusade:" Philanthropy and Declining Civilisations}

\section{Introduction}

The publication of The Ghost Kings, in 1908, marked twenty-three-years since Haggard's first novel, halfway through his literary career and at the height of his commissioned imperial work. The eleven-year period between The Ghost Kings and When the World Shook sees Haggard's desired career in imperial service grow and ultimately meet an abrupt end with the advent of World War I. These two novels represent differing creative strengths, with The Ghost Kings featuring his strongest female protagonist since She, and When the World Shook displaying Haggard's first and only foray into science fiction; both novels feature scenes of philanthropic colonisation, though these depictions of imperial largesse shift from Rachel Dove's divine condemnation of the corrupt Ghost people to the god-like Oro in turn judging the Empire for corruption. Between these two novels, Haggard seeks to redefine his public image through his imperial service rather than his literary output.

Haggard's commissioned work — and in particular his research on settlement colonies - is an essential backdrop for understanding his literary output in the first decades of the twentieth century. In January 1905, H. Rider Haggard was asked by Colonial Secretary, Alfred Lyttelton, to serve as a commissioner to inspect Salvation Army Labour Colonies which provided farm labour training to unemployed city dwellers. Lyttelton wrote, "It is thought that if on inquiry this system is found to be financially sound and to be a real benefit to the poorer classes, it might prove a useful model for some analogous system of settlement from the United Kingdom to the Colonies" (qtd. in Cohen 240). Haggard spent two months in the United States inspecting Salvation Army Labour Colonies: Fort Romie in California, Fort Amity in Colorado, and Fort Herrick in Ohio (Cohen 241). Before returning to England, 
Haggard went to Canada and acquired official commitment from the government to reserve 240,000 acres of land for impoverished British settlers. Upon his return, Haggard submitted his official report which was later published, in 1905, as The Poor and the Land: Report on the Salvation Army Colonies in the United States and at Hadleigh, England, with Scheme of National Land Resettlement. This report details Haggard's solution—a partnership of government and charitable organisations - to national and imperial issues of unemployment, poverty, and dominion control.

The beautiful simplicity of Haggard's scheme was not lost on the general public. On July 13, 1905, the San Francisco Call ran an article on Haggard's report titled "Philanthropic Colonization.” The reporter fancifully wrote,

The report has enough of encouragement to philanthropic workers to make the romance of reality more attractive than fiction. Some day Mr. Haggard may write of marvels done in colonization a true story which will be of more thrilling interest to the public than any of the tales of imagination with which he has delighted readers.

The article continues to describe the Salvation Army labour camp, Fort Romie, near San Francisco that Haggard extolled as a model for "philanthropic colonization." At Fort Romie, "the colonizers, working not for the love of money, but with the motive of kindness for humanity, pocketed the loss, bravely learned the lessons of defeat, persisted and triumphed." The article states that Haggard thought the Salvation Army was too generous and that the colonizers "should be made to pay more for the advantages they have received." The article also notes that colonizers who arrived with only "their natural endowments of industry, muscle and intelligence" were more successful than colonizers who arrived with monetary resources. The article closes, "That is one of the most encouraging truths extracted by the inquiry, for the beauty of the scheme is that it opens the possibility of prosperity and home 
possessing to those who deserve but cannot gain them in the crowded cities." Haggard's report marked the height of his imperial service - a commission that he, ironically, valued more than his writing career although the work was unpaid and was financially supported mostly through his writing.

During this busy period of public service, Haggard conceived the plot for The Ghost Kings with Rudyard Kipling in 1905: "On three sheets of foolscap they wrote alternately a detailed outline of a story about a girl and the boy she grows to love, both children of Natal colonists, who meet the Ghost People, a strange African tribe whose life-force is a tree" (Higgins, Rider Haggard 194). Published in 1908, this imperial romance takes many familiar tropes found in Haggard's earlier works and subverts expectations in ways that make The Ghost Kings one of his finest African adventures. Within The Ghost Kings, Haggard contrasts the benevolent and philanthropic efforts of Rachel and John Dove with the corrupt cruelty of the Ghost Kings. At the same time, similarities between the decaying Ghost civilisation and the Empire are present and these similarities reveal Haggard's concern with enduring civilisations.

The new century gave Haggard an opportunity to reinvent his public persona from successful writer to imperial commissioner; it also gave him a new purpose. During an interview in 1905, the Herald noted that "the Rider Haggard of the new crusade is another man from the jaunty romancer of a decade ago" (qtd. in Cohen 241). Haggard's "new crusade" concerned settling and retraining unemployed urbanites onto farm settlements throughout the Empire. Charitable organisations like the Salvation Army provided the government a philanthropic model and channel to distribute the impoverished throughout the colonies. Although Haggard's report on Salvation Army Labour Colonies was well received, the government decided to leave such matters to charitable organisations as the idea of "state interference" was unpalatable (Cohen 244). Despite his frustration with the government's 
killing any action from his report, Haggard continued to serve in a variety of ways, first with the Commission of Erosion and Afforestation (1906-11), and then a final Royal Commission (1911-1914) to visit and report on Dominions including Australia, New Zealand, South Africa, and Canada. (Cohen 255). It was while in Canada, on imperial business, that Haggard first learned that England had declared war on Germany.

World War I devastated Haggard's sense of imperial purpose - the Empire did not request or need the assistance of an aged romance novelist. ${ }^{15}$ Haggard would never again be called upon for a Royal Commission and the report from his last journey languished, never to be used by an irrevocably changed civilisation. It was during the war that Haggard wrote When the World Shook, with references to this novel found in letters from Kipling in 1916 (Cohen 199). Published in 1919, When the World Shook is a novel of firsts for Haggard: it is his first (and only) novel which contains science fiction elements (i.e. advanced technology and modes of travel such as astral projection), it is his first (and only) contemporary adventure novel in which real world events (i.e. World War I) affect the characters' journey; it is his first novel in which the British Empire, usually a source of virtue and stability, faces destruction (i.e. World War I and Oro). Between The Ghost Kings and When the World Shook, Haggard remained a faithful, imperial servant, convinced that the Empire could be saved through philanthropic colonisation. In his novels, philanthropy is a virtue unique to the Empire, an indication of his civilisation's greatness. However, the potency of philanthropy dilutes in the years between 1905-1919. The growing ineffectiveness of philanthropy is symptomatic of the Empire's waning virtues, a belief found woven throughout Haggard's fiction. Through the following sections, Haggard's depictions of the virtuous Empire in contrast to corrupt, fictional civilisations are used to further illuminate his complex

${ }^{15}$ See John A. McClure's Late Imperial Romance (pp. 11-12). 
relationship with the Empire. In the way these two novels explore decaying civilisations, one can trace the degradation of Haggard's hopes to regenerate the Empire through philanthropic colonisation.

\section{The Ghost Kings: Imperial Redemption through an Individual}

Haggard's preoccupation with ancient or corrupt civilisations speaks to his keen awareness that the Empire would, inevitably, join the ruins that inspired his own romances. Haggard's fascination with the similarities between civilised and savage peoples is a common theme through many of his novels. For Haggard, the veil between savages and civilisation is ephemeral and easily torn away. His most famous character, Allan Quatermain, expresses this sentiment in the introduction to the novel, Allan Quatermain (1887):

Ah! this civilization, what does it all come to? For forty years and more I lived among savages, and studied them and their ways; and now for several years I have lived here in England, and have in my own stupid manner done my best to learn the ways of the children of light; and what have I found? A great gulf fixed? No, only a very little one, that a plain man's thought may spring across. I say that as the savage is, so is the white man, only the latter is more inventive, and possesses the faculty of combination; save and except also that the savage, as I have known him, is to a large extent free from the greed of money, which eats like a cancer into the heart of the white man. It is a depressing conclusion, but in all essentials the savage and the child of civilization are identical. (10)

Quatermain speaks with Haggard's fatalistic tendencies and hints at disillusionment with the imperial narrative that the British Empire was unique and superior to other peoples or civilisations. In this moment, Haggard, using Quatermain's voice, undermines the imperial 
rhetoric that drives many of his characters to explore non-British territories; however, Quatermain's view is that of an old man, uncomfortable in civilisation, too enlightened to live with savages, thus only at home alone in the African wilderness. Similarly to Quatermain, Rachel Dove, in The Ghost Kings, a typical golden-haired, grey-eyed woman, possesses certain virtues of civilized England, but also has access to the "native mind-set" as she has grown up in Africa. Rachel is more at home in the wilderness of Africa than her childhood home of England. However, unlike an aged and weary Quatermain, Rachel sees good in both "savagery" and civilisation, "For her, savagery had virtues as well as civilisation, although it is true of the latter she knew but little" (100).

These "virtues" or lessons on civilisation are gained, not through traditional education, but through observing nature. As a child, Rachel observes two praying mantises fighting and reflects on the parallels between humans and insects: "Men could not be more savage, she reflected, for really their ferocity was hideous. Then a great tear fell upon the head of one of them, and astonished by this phenomenon, or thinking perhaps that it had begun to rain, it ran away and hid itself, while its adversary sat up and looked about it triumphantly, taking to itself all the credit of conquest" (19). Rachel learned from this fight that "nature is always cruel," and that, like these insects, humans take credit for victories which are due to fate (20). In this scene, the praying mantises represent humans, fighting over territory, and due to a tear from God or Fate, one group retreats while the other conquers. Haggard demonstrates that all civilisations are quick to brag of conquests while confusing their prowess for superiority. For Haggard, the ultimate source of conquest is from God, a divine lot to rule whether through technological or economic dominance, although this divine right to rule does not necessarily equate to a moral superiority.

Within Haggard's agrarian vision, truly moral people are grown close to the land, farmers and labourers who draw their virtues from the soil. The virtues which set Rachel 
apart from her father, Mr. Ishmael, and the Ghost people, are acquired from her time spent with the land. As Lindy Stiebel notes, "In the same way that the wilderness can 'improve' civilised man, so can it provide an uncluttered, natural environment for a young girl to grow up in, provided, of course, she remains within her nuclear Christian family" (65-6). The virtues that Rachel displays later in the novel are products of her Christian upbringing and access to the wilderness. This idea of the land producing virtuous, imperial citizens is in perfect keeping with Haggard's philanthropic scheme to settle the unlanded poor onto farms scattered throughout the dominions. Haggard, with many of his fellow imperialists, believed that Britain's divine purpose was to settle and care for all peoples of the earth. Yet this divine mission was frequently subverted by adventurers like Mr. Ishmael, who sought the wilderness as a place to live in decidedly unvirtuous ways. When John Dove questions his past, Mr. Ishmael says, "Now, perhaps I am as well born as you are, and perhaps my luck was rough in other lands, so that I chose to come and live in a place where there are no laws or civilisation" (120). By calling the wilderness lawless and uncivilised, Mr. Ishmael shirks his duty to the Empire. He brings none of the Christian charity which marks John and Rachel Dove's interactions with natives, and thus his existence is anathema to the Empire.

Yet Mr. Ishmael's evil is small in comparison to the corruption found in the Ghost Kings civilisation. Noie describes her father's ancestors as "people who live far to the north, a small people but a strong. They live among the trees, they worship trees; they die when their tree dies; they are dealers in dreams; they are the companions of ghosts, little men before whom the tribes tremble; who hate the sun, and dwell in the deep of the forest" (129). The Ghost people are an ancient race, one whose connection to the land is their life source. They are a hierarchical society ruled by a priesthood fixated on dreams and communicating with the dead. Beneath the priests are various enslaved peoples. When Rachel is brought to their land, she is horrified by the Ghost rulers' treatment of the lower classes. In one 
memorable scene, Rachel watches the "Umkulu people who groaned under the cruel rule of the Ghost-kings" and asks Noie why these people are starved and crying. Noie reveals they are being punished for one man seeking to marry her when he knew she was on a mission from the Mother of the Trees (454). Rachel is angered by the slow, lingering punishment favoured by the Ghost kings and demands they reverse their curses on the people. Rachel threatens them by saying, "I will lift it and set it on to your heads, and you shall perish as they are perishing. Oh! you think me mad, you priests, who kill more cruelly than did the Zulus, and mad I am whose Spirit wanders" (452-3). Rachel challenges the "civilised" punishment of the Ghost kings and seems to imply that although the Zulus seek blood, at least their vengeance is swift and not lingering. The Ghosts kings reluctantly reverse their curse, and from this moment on, they fear her virtuous wrath. When some of the Umkulu people plot to rebel against their enslavement, the Ghost kings avoid their usual lingering punishments and instead "forced them to act as bearers like the others, so that Rachel might not guess their doom" (454). Through her justice, Rachel gains the loyalty of the Umkulus who revere her as a goddess.

While this scene is not directly tied to philanthropy, it is, nevertheless, an important scene which contrasts with both Rachel and John Dove's philanthropic and charitable efforts earlier in the novel. The philanthropic tendencies which they display are in direct contrast to the tyrannical efforts of the Ghost kings. Rachel enters a civilisation built upon the suppression of others, an idea distasteful to her. This is an idea which Haggard often explored and one which he wrote about to the Colonial Secretary upon his final visit to South Africa in 1914:

In the case of the Zulus, civilization has one of the greatest opportunities, for certainly in them there is a spirit which can be led on to higher things. My earnest hope ... is that this opportunity may not continue to be neglected in 
years to come. If so it seems to me that we shall incur a heavy responsibility towards a bewildered people, that we have broken and never tried to mend, and suffer evils to arise of which the effect will not be endured by them alone. (qtd. in Cohen 262)

Haggard saw the Zulus as oppressed and ill-treated by the British and warned that their mistreatment would come back to haunt everyone. Haggard draws upon the Empire's treatment of the Zulus as inspiration for the Ghost rulers' treatment of the Umkulus. The parallels between the Ghost civilisation and the Empire are significant. The Ghost kings are a small yet powerful people who rule over other races by their magical abilities. Their corrupt, out-of-touch upper class revel in the sorrow and poverty of the lower classes. Their kingdom is facing rebellion by various people they have enslaved. The usurper, Eddo, abandons the "secret, ancient faith" to rule as king, not just of their current people, but of other conquered nations (505). When Mother of the Trees, a benevolent queen who has ruled for years, is overthrown by Eddo, the head priest, this signals the beginning of the end of their civilisation, much as Queen Victoria's death was viewed as signalling the end of the Empire's golden age. And yet, for all the parallels between the two civilisations, Haggard has Rachel, a decidedly virtuous, imperial citizen, bring about their destruction through her supernatural goodness. The antidote to a corrupt, decaying civilisation is a woman like Rachel, who embodies imperial virtue. For Haggard, the answer to saving civilisation, and the Empire, was a class of educated, farm labourers who expanded territorial boundaries, not through conquest, but through philanthropic efforts that re-educated and enlightened other races. Ultimately, Rachel saves the man she loves and returns to her ideal role of English wife, but her role is more substantial in the sense that she has toppled a civilisation through sheer virtue, thus enabling the British to claim new land if so desired. Haggard uses Rachel to show how one English woman's imperial virtue can save or destroy a civilisation. 


\section{When the World Shook: Parable of the Empire's Destruction}

If The Ghost Kings displays Haggard's faith in the redemptive virtue of the individual within the project of empire, the following decade would see this faith eroded by larger concerns about the direction of modern civilisation. In 1906, George Nathaniel, Marquess Curzon, (to whom When the World Shook is dedicated) gave a toast in which he lauded the concept and reach of the Empire. Curzon defended the expansion of the Empire as not "an object of ambition," but as "an obligation of duty" (Boehmer 318). He said,

No, the Empire is to them, first and foremost, a great historical and political and sociological fact, which is one of the guiding factors in the development of mankind. Secondly, it is part of the dispensation of a higher Power which for some good purpose - it cannot possibly be for an evil one- - has committed the fortunes of all these hundreds of millions of human beings into the custody of a single branch of the human family. And thirdly, it is a call to duty, to a personal as well as national duty, more inspiring than has ever before sounded in the ears of a dominant people. The cynics may scoff at Empire. The doctrinaires may denounce it from the benches of the House of Commons or elsewhere, and the rhapsodists may sometimes conspire almost to render it ridiculous. But it is with us. It is part of us. It is bone of our bone and flesh of our flesh. We cannot get away from it. We cannot deny our progeny. We cannot disown our own handiwork. The voyage which our predecessors commenced we have to continue. We have to answer our helm, and it is an Imperial helm, down all the tides of Time. (Boehmer 318)

Curzon emphasized that every member of the Empire had an important role to play; no one was greater than another although certain roles are more visible than others. Curzon voiced the sentiments of Empire Haggard grappled with in his novels. Haggard and Curzon both 
agreed that a "higher Power" granted the existence of the Empire and both were concerned with the legacy of perpetuating Empire. Many of Haggard's novels are filled with decaying or ruined civilisations - reminders of a glorious past now turned to dust. Nowhere is this more apparent than in When the World Shook, as Haggard explored the ruination of a 250,000 year-old civilisation and a man (Oro) who steered it to destruction. Through these fantastical civilisations, Haggard sought to draw parallels between these ruined empires and the British Empire. One common attribute that differentiated the British Empire from his fantastical civilisations is British "goodness" or "charity." "In The Ghost Kings, the Ghost people are ruled by a merciless priesthood who exact punishment for the most minor of crimes; When the World Shook is ruled by the Sons of Wisdom who use their knowledge and learning to suppress and rule over all.

Haggard was not alone in lamenting the impending demise of the Empire; William Watson, in 1903, wrote a collection of poems entitled For England with poems titled, "Rome and Another," The True Imperialism," and "The Inexorable Law." A few lines from "The Inexorable Law" speak to the British obsession of the Empire's demise:

We have reigned

Augustly; let our part be so sustained

That Time, far hence, shall hold our memory dear!

Let it be said: 'This Mistress of the sword

And conquering prow, this Empire swoln with spoils,

Yet served the human cause, yet strove for Man;

Hers was the purest greatness we record. (Boehmer 292)

${ }^{16}$ See Helen Gilbert and Chris Tiffin's Burden or Benefit? : Imperial Benevolence and Its Legacies (pp. 1-28). 
Watson's sentiment echoed throughout Haggard's novels: British imperialists wished their Empire to be remembered for the "purest greatness" - a purity and goodness in the midst of great power that differentiated them from the barbarous, evil intentions of civilisations past. Philanthropic colonisation is a mark of "goodness" that features in Haggard's novels as an antidote to issues which threaten the Empire. Faced with a growing, impoverished population, the British government focused on the charitable efforts of societies seeking to resettle the poor to dominion lands at the turn of the nineteenth century. Philanthropy, in contrast to fulfilling the immediate needs of the poor through charity, is a studied and planned effort to solve long-term issues such as hunger, homelessness, or unemployment. Haggard's interest in philanthropic colonisation stemmed from a personal concern with the decline of agriculture throughout England. Haggard's commission from the government to inspect the viability of land resettlement for the poor perfectly encapsulates the lofty aims of an imperialist: to serve the Empire and to better lives of those around them. This lofty goal is one which resonates through many of Haggard's novels. It is an ideal which Wendy Katz uses to claim that "Rider Haggard was an imperial propagandist, a man who made use of every opportunity to advance matters relating to Empire" (153). While Katz correctly identifies imperial themes within Haggard's novels, her claim denies the nuance and contradictions of Haggard's depictions of Empire which prevent him being labelled a “propagandist." This nuance is best exemplified in the shift between Haggard's representation of Empire between The Ghost Kings (1908) and When the World Shook (1919). Between these two novels, Haggard's faith in his agrarian "crusade" is resolute, yet his hope in turning the Empire back to the land is foiled by World War I. The advent of war induces Haggard's latent fatalism and his vision of Empire is subsequently clouded by pessimism; the war dims his faith in regenerating the Empire through philanthropic colonisation as he realises his agrarian vision may be an insufficient solution. In his personal 
diary on 29 July 1914, Haggard writes in his personal diary: "Today we heard that there was a grave peril of a European war, news which racks us all with anxiety.... Poor Englandwithout an adequate army! I am very anxious, and wonder whether Armageddon has come at last” (Higgins, The Private Diaries 3). This anxiety and gloom inspires Haggard to write one of his most original novels through which he explores the perils of modern civilisation. ${ }^{17}$

\section{The Significance of Similarities between Humphrey Arbuthnot and Rider Haggard}

On 10 March 1917, Haggard wrote in his private diary: "Today I finished a romance that I have been writing called $Y v a$. I am rather proud of having been able to do this work in the midst of so many distractions and anxieties, especially as I think it good of its sort. However this may be, it has served to take my mind off all the troubles among which we live, at any rate for an hour or two each day" (Higgins, The Private Diaries 98). Haggard's novel, eventually retitled When the World Shook, provided an outlet and pastime from the "anxieties" of the war; Haggard's need to be useful was partially satisfied while writing. Through the character, Humphrey Arbuthnot, Haggard was able to interact on a metaphysical, philosophical, and spiritual level with the concept of civilisation. In the dedication to George Curzon, Haggard implied readers could view the novel as an allegory of the Empire and its future trajectory by saying: "The application of its parable to our state and possibilities — beneath or beyond these glimpses of the moon-I leave to your discernment" (2). To guide us through this parable, Haggard gives us narrator and protagonist Humphrey Arbuthnot, a handsome, wealthy man, who is a perfectly flawed English gentleman, much like Haggard himself. Arbuthnot claims to be spiritually "superior" to his vicar father, a

\footnotetext{
${ }^{17}$ Haggard and his family also survived a Zeppelin air raid which dropped a bomb about 100 yards from their house. Fortunately, no one was killed in the attack (Higgins, Private Diaries 75-6).
} 
superiority he attributes to "the blood of my Scotch mother which mixed well with his own; perhaps because the essential spirit given to me, though cast in his mould, was in fact quite different — or of another alloy" (10). Like Rachel Dove, Arbuthnot's father is English and his mother is Scottish. Arbuthnot has inherited a mystical spirit from his mother, like Rachel in The Ghost Kings; this mixture of traditional, English Christianity and Scottish spiritualism forms the foundation of characters open to supernatural experiences that a typical Englishman or woman would not be equipped to fully comprehend. Arbuthnot floats through a series of occupations — solicitor, writer, financier, parliamentarian — and wearies of all. He finds fame and wealth as a writer and financier respectively.

Like Haggard's, Arbuthnot's first novel was “an enormous success" which "sold like wildfire and I suppose had some merits, for it is still read, though few know that I wrote it, since fortunately it was published under a pseudonym" (15). Unlike Arbuthnot, Haggard did not use a pseudonym and he was sensitive to insulting reviews and accusations of plagiarism. George Curzon defended him against such naysayers, and to express his gratitude, Haggard dedicated this novel to Curzon. Arbuthnot explains his life as a

failure in the highest sense, though I trust what Stevenson calls a "faithful failure." These have their root in fastidiousness and that lack of perseverance, which really means a lack of faith, again using the word in its higher and wider sense. For if one had real faith one would always persevere, knowing that in every work undertaken with high aim, there is an element of nobility, however humble and unrecognised that work may seem to be. (11)

Arbuthnot feels like a "faithful failure" in that he does not want to persevere when his work, no matter how small, is not recognised. Haggard expressed a similar desire for his work to be recognised in the midst of failure when he finally quit farming in 1917: "I have made nothing, if return on capital is taken into account, but I have gained a vast amount of 
experience, without which I could not have written my books on agriculture, which will, I trust humbly, prove of permanent value and interest in time to come" (Higgins, The Private Diaries 116). As an imperial servant in 1916-1917, Haggard was frustrated by a feeling of uselessness and by the seeming futility of his earlier work to resettle poor labourers onto colony farms which was interrupted by World War I. Arbuthnot displays even more pessimism about the value of his work when he says, "When will man learn what was taught to him of old, that faith is the only plank wherewith he can float upon this sea and that his miserable works avail him nothing; also that it is a plank made of many sorts of wood, perhaps to suit our different weights?" (9-10). Arbuthnot makes two interesting theological points in this sentence: first, he reaffirms the Anglican value of faith over good works; secondly, he says the "faith plank" constitutes many types of "wood" (i.e. religions or beliefs) to match the specific faith measurements of each person. This approach to Christianity and spirituality reflected Haggard's own struggle with the exclusiveness of Christianity and his universalist tendencies. Haggard used Arbuthnot to express frustration with the ineffectiveness of his "charitable" imperial service. Works mean nothing and, in the end, faith is all that remains. Like Haggard, Arbuthnot "sought refuge in that last expedient of weary Englishmen, travel, not as a globe-trotter, but leisurely and with an inquiring mind, learning much but again finding, like the ancient writer whom I have quoted already, that there is no new thing under the sun; that with certain variations it is the same thing over and over again" (39-40).

When their service is no longer needed by the Empire, both Arbuthnot and Haggard resort to travelling the world. This ability to travel "leisurely" throughout the world is the prerogative of wealthy, British subjects who benefit from living in the largest civilisation of the nineteenth and early twentieth centuries. While travelling in the East, Arbuthnot had become acquainted with Indian "thinkers" who "released some hidden spring in my nature 
which hitherto had always been striving to break through the crust of our conventions and inherited ideas" (40). Arbuthnot feels as though his true spiritual self has been stifled beneath British "conventions and inherited ideas" (40). Like Arbuthnot, Haggard's own spirituality, while overtly Christian, was influenced by Eastern religions; themes such as reincarnation or one absolute god known by many names, echo throughout Haggard's novels. ${ }^{18}$ As he aged, Haggard's interest in ancient religions caused him to muse on the future of Christianity: "I wonder what proportion of the inhabitants of this land continues to take any genuine interest in the Christian religion. I wonder who will go to church at Ditchingham on Xmas Day 2223 and to worship at what altars" (Higgins, The Private Diaries 265). Haggard questioned the general population's faith and imagines the potential gods which they might worship in the future. For Haggard, questioning his own beliefs allowed him to form a connection between faith and civilisation. When people, like Arbuthnot, begin to question their faith, it signals a dangerous juncture for an empire. Civilisation is built on traditions and unquestioned modes of thinking, thus Arbuthnot's spiritual awakening is dangerous to the continuity of the Empire. An imperial servant cannot successfully carry out their mission if they openly doubt the value of their purpose.

Thus unmoored from his native religion, Arbuthnot is purposeless and sets sail for the South Sea with no aim in mind other than diversion; however, this aimlessness engenders another question. Arbuthnot says, "If only I could know the truth. Was Life (according to Bickley) merely a short activity bounded by nothingness before and behind; or (according to Bastin) a conventional golden-harped and haloed immortality, a word of which he did not in the least understand the meaning?" (40-1). What is Life? Is it a short moment of light before

\footnotetext{
${ }^{18}$ Haggard denounces placing archaeological findings, like mummies, in museums as "relics of a people who in their way were as great as we are, and certainly more religious, should be sacred" (“Ancient Relics").
} 
darkness, or is it a prelude to something more eternal? This overarching question haunts Arbuthnot throughout the novel and it is a question that Haggard faced in his own life. The pertinence of this question was especially relevant for an imperial servant, like Haggard, whose most prized work was in the furtherance and success of the Empire. The Empire's survival was a topic of interest to many; in 1921, Haggard was asked to speak on "Quo Vadis - or the Empire a century hence" (Higgins, The Private Diaries 231). H. G. Wells, unable to attend the meeting, wrote a "most mischievous letter" in which he predicted the Empire's future: 'I hope and believe that one hundred years hence there will be no British Empire. Either it will have played its part in the development of civilisation and have changed into and given place to a much larger union of free states, or it will have become a danger and a nuisance to mankind, and have followed German Imperialism and Roman Imperialism to the dust heap" (qtd. in Higgins, The Private Diaries 232). Although H. G. Wells wrote this letter in a tongue-in-cheek manner, the humour belied the reality of fear and uncertainty facing imperialists like Haggard; the war left Haggard and his contemporaries searching for remnants of the virtues which they assumed before the destruction. Like Haggard, Arbuthnot finds both consolation and despair in contrasting the virtues of the Empire with the Sons of Wisdom.

The significance of similarities between Haggard and Arbuthnot cannot be overstressed—both are spiritually and socially adrift. Arbuthnot embodies the early career struggles and ultimate financial success that Haggard experienced as a writer. Arbuthnot also voices the spiritual awakening that Haggard experienced through exposure to ancient and Eastern religions. Most importantly, Arbuthnot allows Haggard to interact with the concept of Empire on a metaphysical, philosophical, and spiritual level. By exploring these different levels of civilised constructs, Haggard shows the degradation of faith and virtues which support the Empire. Although his doubts and fears do not dissuade him from public service, 
the value of such work is questionable. After all, his scheme to resettle the poor onto farmland had been pointless if virtuous subjects, like Rachel Dove, were the only bastions against a corrupt civilisation. In this way, Haggard's portrayal of philanthropic colonisation shifts from powerful in The Ghost Kings to laughable in When the World Shook.

\section{Philanthropic Colonisation in When the World Shook}

One aspect of philanthropic colonisation that Haggard alludes to is the work of missionaries in the South Seas providing the natives with "proper" attire. In the book that inspires their adventure, Bastin, Bickley, and Arbuthnot read a work critical of Christian missions and its effect on islanders. The trio observe two pictures, one of native women pre-conversion dressed in nothing but flowers, the second photo post-conversion of a native woman in British clothing. Arbuthnot writes, "In this the native belle appeared after conversion, clad in broken-down stays - I suppose they were stays - out of which she seemed to bulge and flow in every direction, a dirty white dress several sizes too small, a kind of Salvation Army bonnet without a crown and a prayer-book which she held pressed to her middle; the general effect being hideous, and in some curious way, improper" (67). When the native woman is dressed up "properly" in British attire, Arbuthnot writes there was something "improper" about it. Arbuthnot is uncomfortable with this aspect of philanthropic colonisation because Christian charity distorts native, edenic innocence into a hideous mockery of the Empire. To transform the native women into proper, British Christians, the missionaries dress the women in discarded clothing donated by British women. The Empire, as a concept, had been successful in part because it legislated and imposed a set of virtues onto its colonies. To be a successful member of the Empire meant adopting these virtues, even though the results might be grotesque. Conversely, a missionary could take satisfaction as an Empire member when they successfully garbed their converts in symbols of virtue. Arbuthnot's discomfort is not 
centred on converting the natives to Christianity, rather his discomfort stems from the impoverished symbols of charity. Haggard strikingly condemns the stinginess of Christian charity in this scene; British Christians are sending their broken undergarments and tattered bonnets as tokens of charity to new colonies. If an empire's occupation strategy includes the soft force of philanthropy, the success of this strategy can be measured by the wares it sends to woo its newest conquests. Arbuthnot and Haggard are both discomforted by the shabbiness of Christian charity, not in a religious sense, but in a symbolic sense in which the Empire is reflected back grotesquely in the picture of the native woman dressed in missionary hand-medowns. This "hideous" and "improper" picture reflects an image of the decaying Empire; after all, a rich or, at least, virtuous country would be capable of sending proper garments. In the same scene, Haggard uses Bastin and Bickley to explore a fracture in the Empire's continuity. Bastin and Bickley's debate over the value of missionaries in the South Seas allows Haggard to explore the degradation of Christian missions. Bastin, enraged by the book critical of South Sea missionaries, says, "I should like to go there and expose this vile traducer of my cloth" (68). Bickley replies, "So should I ... and expose these introducers of consumption, measles and other European diseases, to say nothing of gin, among an innocent and Arcadian people" (68). Bastin asks, "How can you call them innocent, Bickley, when they murder and eat missionaries?" to which Bickley wryly answers, "I dare say we should all eat a missionary, Bastin, if we were hungry enough" (68). Bastin represents the lofty ideals of Christian missionaries who, when Britain first began expanding their Empire, launched wholeheartedly into proselytising missions; Bickley represents a newer faction in the Empire, a scientific man who criticises and even pokes fun at the foolish faith of missionaries. Bickley views the South Sea islanders as "an innocent and Arcadian people" to whom the missionaries introduced disease and vices such as alcohol (68). Bastin and Bickley represent two factions within the Empire: Bastin, the devoted and faithful servants of the 
Empire, and Bickley, the critical and doubting inheritors of the Empire. Bastin's type, specifically Christian missionaries, were crucial in spreading imperial virtues; Christian missionaries provided soft power to gain control over native populations with limited military force. By the turn of the nineteenth century, Bickley's type rose to prominence in that scientific, sociological approaches to charity were developed which allowed for measuring the success of Christian missions. As sporadic charity was replaced by strategic philanthropy, the British became aware of the destruction their earlier missionaries had wrought. Bickley is critical and sceptical of all around him - a luxury reserved for the heirs of British dominance. Haggard, as Arbuthnot, provides a conflicted and uncertain viewpoint; in fact, both Haggard and Arbuthnot prefer to withdraw from scenes of imperial conflict to reflect on "higher abstracts."

In When the World Shook, Haggard uses philanthropic colonisation to reveal the depth of corruption and hypocrisy which permeates the Empire. Unlike The Ghost Kings which shows John and Rachel Dove successfully dispensing charity through Christian missions, Arbuthnot, Bastin, and Bickley confront the grotesque and hideous farce that has become Christian missions. Bastin, a clergyman, refuses to accept this truth and embarks on a quest to redeem the image of Christian missionaries; however, his attempts are too late as the decline in quality missions and charity is symptomatic of deeper imperial decline. It is these concerns of imperial decline which Haggard explores through Oro and the Orofenans.

\section{Traces of the Empire in Orofena}

Haggard confronts Arbuthnot, Bastin, and Bickley with an ancient, withered civilisation that is eerily similar to the Empire. When the trio are washed upon the shores of Orofena, they encounter the Orofenans whom Arbuthnot describes as "a wonderfully handsome people, tall and straight with regularly shaped features and nothing of the negro about them" (112). 
Victorian eugenics is revealed in this description as Haggard frequently describes the remnant populations of his superior, lost civilisations in white terms. Arbuthnot also describes the Orofenans' statue of their god Oro: “Allowing for an enormous debasement of art, they were essentially identical in the facial characteristics. This would suggest the descent of a tradition through countless generations" (184). Although their artistic ability is inferior to that of their ancestors, the Orofenans have the distinction of being descended from a great civilisation which, for Arbuthnot, imbues a level of respect. After all, the British were great admirers of ancient civilisation such as Egypt or Rome to whom they liked to compare and contrast their own imperial achievements. Fascinated by their origins, Arbuthnot learns that the Orofenans had no mythology as to how they reached Orofena, believing they had always been there. Arbuthnot writes,

My own opinion, which Bickley shared, was that they were in fact a shrunken and deteriorated remnant of some high race now coming to its end through age and inter-breeding. About them indeed, notwithstanding their primitive savagery which in its qualities much resembled that of other Polynesians, there was a very curious air of antiquity. One felt that they had known the older world and its mysteries, though now both were forgotten. (141)

Citing Bickley as corroboration, Arbuthnot gives his theory that the Orofenans are a "deteriorated" people, leftovers from a "high race" which met its end through "age and interbreeding." Arbuthnot recognises the markers of an advanced civilisation (Sons of Wisdom) as he is descended from the world's currently most advanced civilisation. Keeping in mind that Haggard intended this novel as a parable, it's possible to assume that Haggard imagined a world when British people would be as the Orofenans_- "shrunken and deteriorated" from their current, cultural heights. This fear of imperial deterioration connects to the equally 
feared loss of land; losing control to natives or other countries was a threat to the continuity of the Empire. ${ }^{19}$

One danger to the Empire, and civilisations in general, that Haggard frequently explores is "inter-breeding." In almost every novel, Haggard features at least one "halfbreed" character that belongs to neither world. Interracial characters, like Noie from The Ghost Kings, represent an existential threat to their families, tribes, and civilisations. Haggard's fear of interracial pairings results in an unhappy ending (i.e. death) in every case for any British character who deviates (Heart of the World, Montezuma's Daughter, Marie, King Solomon's Mines). Haggard admired, non-British, non-white peoples and civilisations, yet he believed that all people groups benefited from marrying amongst their own. At the point of writing When the World Shook, well into the twentieth century, Haggard witnessed the results of British colonisers intermingling with native peoples and feared their interracial children would result in the destruction of the Empire. In fact, Haggard viewed interracial children as the sign of a decaying civilisation (i.e. Noie from The Ghost Kings is descended from the decayed Ghost-people and the soon-to-be weakened Zulus). In Haggard's novels, interracial couples signal the demise of a civilisation. Thus, Arbuthnot's assessment of the Orofenans is a window into Haggard's own fear of the British becoming nothing more than a "remnant" through interracial coupling.

Through the character Oro, Haggard voices concern about the degenerating Empire, its people, and modern civilisations; Haggard also places his agrarian vision of rebirth into Oro's superhuman mouth. When the trio find Oro and Yva, they encounter living relics from a civilisation infinitely superior to that of Britain. Oro is a king from a lost civilisation (called

\footnotetext{
${ }^{19}$ For a discussion on how Haggard's choice to write within the romance genre is a response to the British Empire's decline, see Nathan K. Hensley's Forms of Empire: The Poetics of Victorian Sovereignty (pp. 194-242).
} 
the Sons of Wisdom) who used advanced knowledge to sleep for 250,000 years in the hopes that when awakened, he could create a new civilisation. He learns as much as he can of the modern world from Bastin, Bickley, and Arbuthnot, but is unimpressed by their descriptions. Oro says, "I begin to think that I did not allot a sufficiency of ages, since I perceive from what you tell me, that the learning of the new races is as yet but small" (334). In a chapter called, "Oro and Arbuthnot Travel by Night," Oro uses Arbuthnot as a guide, through astral projection, to tour the modern world's greatest civilisations. Oro expresses disgust at the state of the modern world which is in the middle of World War I. To begin with, Oro and Arbuthnot go to Britain where Oro is disgusted by a host of issues: women's suffrage (430), opulent wealth (430), and soldier recruitment (432). Oro passes from a wealthy party to a public house to an empty church service to a crowded music hall, stopping last of all at a Salvation Army service which Oro says, "I do not understand these rites, but at last in your great and wonderful city I have seen something that is pure and noble " (433). Oro and Arbuthnot tour France, Germany, Turkey, America, China, Japan, etc., and witness key moments from World War I, such as the Armenian massacre and the sinking of the Lusitania. Passing over Australia and New Zealand, Oro expresses great interest in the agricultural prospects of these two countries and laments (much as Haggard did): "But where are the people ... I see few of them, though doubtless some of the men are fighting in this war. Well, in the days to come this must be remedied" (449). ${ }^{20}$ Arbuthnot proudly notes that Oro praises the English rule over India "because of its rather autocratic character. Indeed he went so far as to declare that, with certain modifications, it should be continued in the future" (450). After their tour of the world's civilisations, Oro says, "Let us go home ... I grow tired of this war of your Christian peoples. It is no better than that of the barbarian nations of the early

${ }^{20}$ Haggard wishes the "landless man [Englishmen] could be brought to the manless land [Australia]" ("Empire Trade Commission”). 
world. Indeed it is worse, since then we worshipped Fate and but a few of us had wisdom. Now you all claim wisdom and declare that you worship a God of Mercy" (447). Oro's tour of Britain is the most thorough and Arbuthnot clearly is discomforted by the impression London, the heart of the Empire, makes on Oro.

Haggard paints an uncomfortable and contrasting image of London that Oro uses as reason to flood the world again. World War I is a dark backdrop against which Haggard explores all that is ugly and twisted in human nature. Oro plays "god" and decides the world is too savage to be saved and thus prepares to destroy it once more. Haggard uses this chapter to fictionally delve into what he perceived as the social and moral decay of Britain. As Oro, Haggard was able to play judging and impartial "god," and, as Arbuthnot, Haggard played a defenceless and disquieted British subject. As an imperial servant, Haggard's faith and trust in the Empire was shaken by World War I. The certainty and steadiness of the Empire that featured in his earlier novels is subdued in this novel; whereas British virtues were given credit for Rachel Dove's moral character, those same virtues are absent in When the World Shook. Haggard, through Oro, notes that too many people are packed into a music hall where a "horrible and vulgar song full of topical allusions, which was received with screams of delight by the enormous audience" (432) whereas "hearers are not many" at a poorly attended church service (431). In Haggard's earlier novels, the Empire is portrayed as a virile and noble entity; in When the World Shook, the Empire is marked by debauchery and ignoble citizens. In fact, the only aspect of British rule that Oro complimented was the authoritarian regime they established in India, the "purity and nobility" of which one must doubt.

Haggard uses Oro not only to condemn the Empire, but all Western civilisationswhich speaks to Haggard's despair over modern civilisation. Oro gives a damning description of the doom facing both British and Western civilisation. He says, 
"You think that these civilisations of yours, as you are pleased to call them, are saved, do you?" he sneered. "Yet, even if Bickley were right and I should die and become powerless, I tell you that they are already damned. I have studied them in your books and seen them with my eyes, and I say that they are rotten before ever they are ripe, and that their end shall be the end of the Sons of Wisdom, to die for lack of increase. That is why I would have saved the East, because in it alone there is increase, and thence alone can rise the great last race of man which I would have given to your children for an heritage. Moreover, think not that you Westerners have done with wars. I tell you that they are but begun and that the sword shall eat you up, and what the sword spares class shall snatch from class in the struggle for supremacy and ease." (574)

Oro prophesies the entire world, except the East, will self-destruct. Oro predicts the West will continue to fight wars, and that what people remain after the wars will be caught up in class war. Haggard, as an agricultural reformer, lamented the lack of "increase" or the lack of people to populate colonial land. Oro (and Haggard) predict the same fate for the Empire as the Sons of Wisdom: a lack of children will result in the demise of their civilisation. Under the gloom of this prediction, Bastin gives a wonderful reply: "I think it right to tell you, Oro ... that the only future you need trouble about is your own. God Almighty will look after the western civilisations in whatever way He may think best" (575). Bastin, as a holy fool, gives wise answers at the most unexpected moments. Bastin tells Oro not to concern himself with the fate of the West as God, not Oro, will judge and decide its outcome. Perhaps this answer is one that chastened Haggard to stop fretting on the Empire's "impending doom," for, as a fatalist, he believed that whatever was meant to be would happen. Although Oro finds nothing redeemable about Western or British civilisation, Arbuthnot, like Haggard, sees the 
flaws of modern civilisation and, at times, may even decry the depths of its evil, yet ultimately remains faithful to the ideals of the Empire.

Through Oro and the Orofenans (remnants of the Sons of Wisdom), Haggard delves into his fear of the Empire and Western civilisation deteriorating into oblivion after the war. New concerns such as faithless and debauched citizens, interracial children, and unpopulated farmland threaten to overwhelm the Empire. The novel allows Haggard to interact with fictional gods and lost civilisations while examining the reality of horror and tragedy of World War I. This juxtaposition of fantasy and reality creates an environment in which the mythic qualities of civilisation are present as well as the stark concerns of Empire. The science fiction genre gives Haggard the freedom to create a fantastically ancient civilisation, but also one in which the Empire is faced with various levels of existential threats. Connecting the Orofenans and the Empire allows Haggard to imagine the "Armageddon" which he envisions at the start of the war. He plays both plaintiff and defence while exploring the merits of the Empire and modern civilisation. Although modern civilisation is vilified for its barbarity, Haggard exonerates the Empire in hopes it can return to the virtues and faith of its birth.

\section{Conclusion}

Although he is still confident in his agrarian vision, Haggard grapples with new fears and concerns brought on by the war-fears such as uselessness in old age, interracial children, waning Christian faith, and declining imperial virtues. The link between Haggard's public and agricultural work provides an additional layer through which to view his novels. Between The Ghost Kings and When the World Shook, one can mark the shift in Haggard's confidence. While Rachel and John Dove use tools of philanthropy (dispensing food and tools) to build relationships with natives, Bastin offers no practical or charitable assistance to the Orefenans; 
rather he reverts back to the "fire and brimstone" preaching of the earliest missionaries, thus signalling a regression in Christian mission efforts. Additionally, Haggard's depiction of fictional civilisations alters between 1908 and 1919; while Rachel Dove's imperial virtue enables her to bring about the Ghost civilisation's destruction, Arbuthnot and his friends are faced with uncomfortable and unflattering comparisons between the Sons of Wisdom and the British Empire. This shift from portraying the Empire as virtuous to immoral illuminates Haggard's use of philanthropic colonisation in both novels. In The Ghost Kings, Haggard uses Rachel's charity to extend the Empire and to demonstrate the effect one individual's virtue can make in saving or destroying a civilisation; in When the World Shook, Haggard shows the depth of imperial corruption through the decay of Christian missions. Through Arbuthnot and Oro, Haggard struggles to understand the fate of the Empire; using both characters to grasp the concept of civilisation, Haggard concludes that, although the Empire has serious flaws, it ultimately is worth saving or trying to save. Between these two novels, Haggard's hope to regenerate the Empire through philanthropic colonisation fades, yet he never ceases his crusade to resettle people onto farmland. 


\section{Chapter Two}

\section{Zealot, Renegade, and Reformer: \\ Haggard's Vision for the Empire}

\section{Introduction}

The move between zealot, renegade, and reformer character types reveals Haggard's developing sense - from the late 1890s through to 1919 — that the Empire needed to be rejuvenated. He initially believed that individuals could facilitate the reformation of empire, but by the time of World War I, he had lost this belief and grown to accept that minor reforms of existing institutions and practices were the only way to preserve the Empire. Although many of Haggard's novels overtly support the Empire and its causes, quite a few are populated by zealous or renegade missionaries, men who are seized by a fanatic desire or madness to proselytise unreached peoples who are of no immediate interest to British colonisation efforts. These characters break from the institutional church to turn back to the ancient roots of their faith - a break which is necessary to foster rebirth of their religion. The fanaticism of these characters speaks to Haggard's longing for a pure faith — a faith that relies on glimpses of truth found in all organised religion. While his own relationship with organised religion fluctuated throughout the years, Haggard generally depicts Christianity as ultimately triumphing over whatever foreign gods or native magic it encounters. While this pattern contributes to his being labelled "formulaic" or an "imperial propagandist," these broad claims, while superficially true, ignore the nuance with which Haggard writes Christian missionaries; characters, such as John Dove, who break away from the formal Church of England to pursue an unsanctioned, divine mission.

In an unpublished thesis titled "Spirituality in the Fiction of Henry Rider Haggard," John Senior argues that Haggard's fiction "takes the form of a spiritual monologue in which Haggard addresses issues of life and spirituality trying to relate them to some sensible 
pattern, although, with each new attempt at rationalization or reconciliation, the underlying inconsistency and confusion of his age becomes more apparent” (26). Although Senior correctly identifies Haggard's use of the romance genre to develop his personal theology, he downplays the ways that spirituality is inextricably linked to the civilisation in which one is born. For Haggard, each civilisation is tied to a religion which draws its particular truths from an absolute Truth. This thought is best summarised in a scene between Holly and immortal Ayesha in She. In response to Ayesha's queries about modern religions, Holly explains the tenets of faith for both Christianity and Islam. Having her questions answered, Ayesha says: "Mark, my Holly, each religion claims the future for its followers; or, at least, the good thereof. The evil is for those benighted ones who will have none of it; seeing the light the true believers worship, as the fishes see the stars, but dimly. The religions come and the religions pass, and civilisations come and pass, and naught endures but the world and human nature" (She 408). In keeping with Ayesha's words, Haggard's depiction of Christianity conquering all other gods speaks more to his view on the cyclical nature of civilisations rising and falling rather than to his faith in the truth of Christianity.

Haggard, as a proper English gentleman, publicly presented himself as a Christian throughout his life, yet his inner spiritual life was much more uncertain, inconstant even to his public image. Personal views, such as Ayesha expressed, were reserved for the realm of romance. Labelled "an authentic heretic" by Gerald Monsman, Haggard attempted to resolve the disconnect between his "overt stance and covert feelings" through zealous or renegade characters (H. Rider Haggard on the Imperial Front 42). What better way to express these subversive feelings than through characters compelled by a divine mission to break away from the formal church? Like Haggard, these characters overtly stay faithful to Christianity, yet they allow their covert feelings to propel their actions. These covert feelings and subsequent actions reveal the discontinuity between their Christian and imperial identities. If 
these characters' main concern was to expand the Empire, their actions would need to fit more clearly within a unifying vision of Empire; the disconnect between these figures and homeland institutions reveal fractures in imperial ideology, as well as challenges to Victorian values and cultural norms. Therefore, while their missionary efforts eventually succeed in extending the Empire, the means by which they achieve this reflect Haggard's concerns with the growing corruption and degradation of imperial institutions.

Coupled with his nebulous faith, Haggard's role as a social and agricultural crusader placed him as an unfulfilled reformer. Haggard worked within the imperial system but envisioned a rebirth of the Empire centred on returning people to the land. His vision for the Empire is laid out in The Poor and the Land, non-fiction report based on his survey of Salvation Army Labour Colonies in 1905. In its introduction, Haggard lays out his solution for both urban poverty and unemployment: encourage unemployed, urban dwellers of sound character to purchase colonial farmland through state subsidised loans which would be administered by charitable organisations. Haggard terms the scheme as "one of imperial investment, not imperial charity" (xiii), an important distinction as Haggard's concern is to decrease impoverished people's dependency on public benefit. At the same time, he seeks to join both state and charity into this project as he assumes the motives of the religious (Salvationists) to be more pure than private business. Haggard even addresses the concerns of those who say the Salvationists are a "set of cranks" or "religious fanatics" by saying they "are fulfilling their great and self-imposed office with a whole-hearted humility and patience worthy of the first founders of the Christian faith" (xxviii). Haggard's inclusion of religious fanatics in his scheme for rebuilding the Empire extends to his novels and challenges the essential role which religious fanatics will hold in creating a virtuous, agrarian civilisation.

The way in which Thomas Owen from The Wizard, John Dove from The Ghost Kings, and Basil Bastin from When the World Shook dissent from authority and reach out to 
natives enables Haggard's vision of philanthropic colonisation. Before delving into each character, it is important to point out the similarities: all three come from privileged, gentry backgrounds which they forsake to pursue their mission; their divine mission is not formally sanctioned or funded by a church or mission society; all are prepared to die for the sake of their mission; all utilise the charity of knowledge to develop relationships with the natives. These clergymen represent three character types: the zealot, renegade, and reformer. The distinction between these types is subtle yet points to an evolution in Haggard's own vision of the Empire. Thomas Owen from The Wizard (1896) is a zealot, possessed by madness to carry the gospel to the Amasuka tribe, a tribe which killed a previous missionary unable to physically prove his faith; John Dove from The Ghost Kings (1908) is a renegade possessed to seek martyrdom which drives him far from civilisation; Basil Bastin from When the World Shook (1919) is a reformer determined to redeem critics' perception of Christian missions. For Haggard, religion and civilisation are intertwined - the spiritual lethargy or decline of religion signals the impending doom of a civilisation. Thus, these characters' mission, indeed Haggard's it might be argued, is to win people to a pure and ancient faith which will foster an edenic, agrarian society.

\section{Thomas Owen: Zealot and Self-Funded Messenger}

Haggard uses the character of Thomas Owen, from The Wizard, to demonstrate the zealous and pure faith needed to rejuvenate the Empire. In the meanwhile, Haggard's own zeal for agriculture grew during the writing of this novel (1896). At the same time, political events, such as the Transvaal crisis, affected the Empire's future occupation of South Africa, an issue close to Haggard's heart as he firmly believed it was Britain's calling to rule and develop the country (Higgins, Rider Haggard 166). When Nada Burnham, a family friend's daughter, died as a result of an illness contracted during a siege in South Africa, Haggard decided to 
dedicate The Wizard to her memory. The significance of this dedication lies in the following line: "I dedicate these tales — and more particularly the last, that of a Faith which triumphed over savagery and death" (2). The emphasis of "a Faith" triumphing "over savagery and death" speaks to Haggard's fictional use of The Wizard to correct the wrongs of reality; in The Wizard, Christianity wins over the native religion, a reflection of how imperial reality should appear in Haggard's mind. Interestingly, Christianity wins in this case, not due to military might, but due to the zeal of an unsanctioned missionary. As a zealot, Thomas Owen is integral in turning the Empire, both spiritually and politically, back to its ancient roots; this role is also crucial to Haggard's agrarian vision of Empire as zealots are needed to lead the exodus from city to farmland, both in England and abroad.

As a zealot, Rev. Thomas Owen's faith and purity are important as those qualities propel him to preach to the Amasuka tribe - a tribe the Church refuses to further proselytize as it is too far from imperial holdings. Before developing into a zealot, Owen is a man of conscience whose birth and privilege enable him to pursue any mission he chooses. Owen begins his adulthood by passing on a sizeable inheritance and seeking to make a social difference in the slums. Somewhere during these three years, Owen decides to accept a comfortable living of $£ 2,000$ a year, perhaps revealing weariness with the poverty by which he was surrounded in the slums. Owen's social status, one that mirrors that of both John Dove and Basil Bastin, enables his philanthropic tendencies and allows him to dabble in poverty without the bleak prospect of this as a permanent status.

Three years into his social work, Thomas escapes to an inherited living where the moral and philanthropic work is limited. In fact, the Salvation Army's work renders Owen's hibernating zeal useless as two of the three town drunks have already been reformed. Haggard's insertion of the Salvation Army is an interesting moment in the text as he would 
later defend them from accusations of religious fanaticism in The Poor and The Land. ${ }^{21}$ While the Salvationists' zeal successfully reformed two town drunks, Owen must contend with the overall spiritual lethargy of the village. Owen presides over a sleepy village of three hundred people, of whom only thirty-nine attend the service at which the Deputation (missionary) shares his tales of the Amasuka tribe. It's during this particular service that Owen discovers a new "divine mission," one that will take him far from the spiritually drowsy congregration to the dangers of preaching to a tribe uninterested in Christianity.

Haggard further denotes the spiritual degeneration of Owen's parish by describing the church and village of Busscombe as "a beautiful church, ancient and spacious; moreover, it had recently been restored at great cost. Seven or eight hundred people could have found sittings in it, and doubtless they had done so when Busscombe was a large manufacturing town, before the failure of the coal supply and other causes drove away its trade. Now it was much what it had been in the time of the Normans, a little agricultural village" (4-5). There are two things to note about this description: firstly, the church was restored at a "great cost" and could seat $700-800$ people although only 39 people attend this particular service. The opulence and waste of restoring this church for a few Christians is compounded by the fact that "three were fast asleep and four were dozing" (5). Owen is overcome with "bitterness and disappointment" by the small attendance and the disinterested audience in which he had hoped to "arouse the indifferent to a sense of duty towards their unconverted black brethren in Africa, and incidentally to collect cash to be spent in the conversion of the said brethren" (5). The narrator notes that "the beauty of the weather, or terror of the inevitable subscription, prevailed against him" and Owen resigns himself to making up the difference of the donation from his own pocket (5-6). These village Christians, although by no means impoverished, do

${ }^{21}$ See Norman Murdoch's Origins of the Salvation Army (pp. 151, 162-64). 
not have the same altruistic pockets or convictions as Owen. His disappointment stems from an idealistic, zealous desire to reach the poor, but also comes from an inflated sense of entitlement — as a reverend, Owen expects his parishioners to respond with the same charity of which he is capable. The congregation is unmoved by the plight of their "unconverted black brethren," but Owen feels called to leave all behind in Busscombe to convert the Amasuka tribe even though the venture may cost his life. Owen's zeal exceeds the institutional limits of the Church, thus highlighting a discrepancy between the vibrancy of his faith and the deficient faith of his parishioners.

The village of Busscombe also provides an opportunity for Haggard to further connect his developing theory of agriculture and imperial decline. Busscombe is a shadow of its formerly prosperous days. When coal mining and other trade failed, residents moved away in search of employment leaving behind only the farmers. As his novels and non-fiction writings reveal, Haggard strongly associates the health and strength of an empire based on able-bodied men's access to farmland. As industrialization jobs such as mining or factory work fail, the poor starve for lack of opportunity. Busscombe's population has dwindled and the narrator recalls the historical continuity of farming by mentioning a time of great upheaval in English history, the time of the Normans. The Norman reference places Busscombe in the past, well before the Empire had conquered most of the world. Busscombe natives are concerned with their own lives and do not seem aware of the civic burden that imperialism places upon them. This small passage illustrates Haggard's belief that farming was the foundation of the Empire; industrialization may have propelled its massive growth, but when industrialization fails, it will be saved by farming. Haggard sought to send out a body of trained, imperial farmers to solidify and stave off the deterioration of the Empire, although decay was present at the heart of the nation. 
Owen, as a member of the upper-class, has been educated as a British gentleman, but does not possess the usual characteristics of imperial loyalty and conscious colonisation. He is an idealist, born to leisure and seized by a religious zeal to convert the Amasuka tribe. When the "battered-looking" Deputation preached and shared his personal "experience and sufferings in the Cause amongst savage tribes," Owen finds a purpose for which he is willing to sacrifice his life (6). The fervency of his faith causes his family to doubt his sanity:

To this hour, indeed, those who stand in his place and enjoy the wealth and position that were his by right, speak of him as "poor Thomas," and mark their disapprobation of his peculiar conduct by refusing with an unvarying steadiness to subscribe even a single shilling to a missionary society. How "poor Thomas" speaks of them in the place where he is we may wonder, but as yet we cannot know - probably with the gentle love and charity that marked his every action upon earth. But this is by the way. (16-7)

When Owen renounced his inheritance, his family thought him mad. Due to his madness, his family refuses to donate to any missionary society. He seeks a higher purpose outside that which his birth entitled him and he finds that purpose as a zealot.

To emphasise the purity of his mission, Haggard sends Owen out with no mention made of needing to raise funds through subscription or being sent by a specific missions society. One can assume the first is based on Owen's ability to leave Busscombe fairly quickly without mention of needing money. The second can be inferred from the African missionary's comment: "My Society does not ask you to subscribe towards the conversion of the Children of Fire. Until that people is conquered - which very likely will not be for generations, seeing that they live in Central Africa, occupying a territory that white men do not desire - no missionary will dare again to visit them" (7). The Society does not help Christianize tribes who occupy land of little or no value to the Empire. This passage clearly 
indicates that Christian missions work closely with imperial colonisation schemes. Haggard unveils the imperial agenda of religious missions: "help" is withheld from unconquered people whose land the British do not desire. Owen's "Divine mission" would not have been supported by any mission society as it does not have an imperial value. Haggard contrasts the corrupt motives of Christian mission societies with Owen's own pure faith: "It was utter and virgin; it was not clogged with nineteenth-century qualifications; it had never dallied with strange doctrines, or kissed the feet of pinchbeck substitutes for God" (18-9). Owen's financial independence, coupled with his pure faith and charitable tendencies, position him as the perfect and ideal zealot.

Owen's pure motives are contrasted with those of the weary Deputation missionary to whom he gives his comfortable living; the African missionary says, "And I have worked, ay, until my health is broken. A labourer indeed! I am a very hodman, a spiritual Sisyphus. And now I must go back to carry my load and roll my stone again and again among those hopeless savages till I die of it—till I die of it!” (8-9). This society missionary moans about the "hopeless savages" and the effect that this hopelessness has on his health. He is beleaguered by his fate and does not have faith or purpose. Owen on the other hand is willing to sacrifice his health for the opportunity to convert the Amasuka tribe. Haggard uses the Deputation character as a foil to Owen, and yet this character also represents the spiritual weariness that affects late-nineteenth century missionaries. Haggard uses this missionary's mixed role of faith-and imperial-bearer to demonstrate the spiritual lethargy which infects the Empire. After all, if the Deputation views the natives as "hopeless," then this is a clear indication that imperial colonisation efforts are weakening; the Deputation's weariness speaks to a dangerously widespread imperial weariness. It is this weakness and misgiving that Haggard seeks to counteract through the zeal of characters like Owen. 
Unlike other missionaries, Owen does not use Western knowledge to deceive the Amasuka tribe; rather he is aided by divine visions. Owen's faith sets him apart from those missionaries who first witnessed to the Amasuka. The Amasuka asked those missionaries to demonstrate their faith and rejected their teachings as false when they were unable to prove it. This display of logic is rare for Haggard's fictional tribes; most of his fictional tribes are awed by Western scientific or technological marvels, such as quinine or guns. However, the missionaries do not attempt any such subterfuge and one is killed in the process. Thus, when Owen arrives, King Umsuka is wary and asks:

Now, what is your business with me, and why do you come from the white man's countries to visit me? I have heard of those countries, they are great and far away. I have heard of the white men also-wonderful men who have all knowledge; but I do not desire to have anything to do with them, for whenever they meet black people they eat them up, taking their lands and making them slaves. Once, some years ago, two of you white people visited us here, but perhaps you know that story. (100-1)

White men have knowledge, but Umsuka does not want to meet them because white men enslave black people and steal their land. Similar to the Sons of Wisdom in When the World Shook, the British people are known for their knowledge and are feared due to the power it gives them over other peoples. Haggard acknowledges the detrimental effect that philanthropic colonisation has on native populations. Whenever a native people accept knowledge or charity from the British, they are subjugated. Christian missions are an extension of imperial philanthropy, a soft power that ensured a successful colony in exchange for education or gifts.

Owen is an unusual protagonist in the sense that he does not entice the Amasukans with imperial knowledge or gifts; he brings only the gift of a new god. The god he shares 
does not come with the traditional duty to Empire or Queen; rather, Owen rarely mentions England and does not seem bothered whether or not his mission furthers the Empire. Instead, Owen views himself as an imperial servant of the Heavenly King: "I, Messenger, who am the servant and the ambassador of the King of Heaven, give greeting. A year ago, King, I sent to you saying that the message which was brought by that white man whom you drove from your land had reached the ears of Him whom I serve, the High and Holy One, and that, speaking in my heart, He had commanded me to take up the challenge of your message" (26). Owen is an ambassador on an imperial calling to spread the kingdom of God. He calls himself "Messenger," aligning himself with the New Testament prophet, John the Baptist, who "appeared, baptizing in the wilderness and proclaiming a baptism of repentance for the forgiveness of sins" (Mark 1:4). Owen's strong faith enables miracles to occur, miracles which cause the tribe to view Owen as a wizard. Owen tells them he does not have magic, rather he has faith and scientific knowledge which he will use to expose the natural causes of their lightning god. Haggard uses Owen as a "Messenger" to share a faith which aligns more closely to the first Christians rather than the modern, British followers. As a zealot, Owen shares the faith which propels his actions, but he is also willing to share the scientific knowledge of the place from which he left. Similarly, Haggard developed a zeal for agricultural reform which launched him into action and a desire to proselytise to those around him about the virtues of farming.

In order to successfully fulfil his divine mission, Owen had to leave England to find the right people. For example, when the Amasukans agree to learn about Christianity, "They listened to him attentively, debating the new doctrine point by point; for although they might be savages, these people were very keen-witted and subtle" (115). Unlike the dull-witted tribes usually described in imperial fiction, Haggard portrays the Amasukans as intellectually capable of questioning and debating the truth of Christianity. Although they are considered 
"savages" by the mission society, Owen discovers the tribe to be equal, if not superior, to his previous congregation. Unlike his parishioners in Busscombe, the Amasukans are curious and keen observers, unwilling to sleep through his sermons. One could attribute this to novelty, as in the Amasukans were eager to learn something new, but the case could be made that Haggard was comparing the lethargic faith of English natives to the active faith of "savages."

Part of Owen's success at converting the Amasukans is his ability to use language that appealed to their militaristic society. Utilising language similar to that of the Salvation Army, Owen is asked by Nodwengo, "Messenger ... you have told us of baptism whereby we are admitted into the army of your King; say, have you the power of this rite?" (116). Nodwengo is baptised and becomes a "soldier for Christ." Even as Owen dies from poisoning, he admonishes the Amasuka to "be faithful, cling to the Cross, and do not dare to doubt your Lord, for He will be your Captain and you shall be His people" (260). Using this warlike language appeals to the Alaska and it ultimately encourages a great many Amasuka to convert. As the king, Nodwengo, and many leaders begin to convert, Owen sends his servant John, "with other messengers, on a three months' journey to the coast, giving them letters acquainting the bishop and others with his marvellous success, and praying that missionaries might be sent to assist him in his labours" (145). Owen, although not on a funded mission, seeks the support of the church now that his efforts have proven successful. Although it remains unclear if the church will send additional missionaries to support the work that Owen begins, this is of little importance as he has achieved his mission.

One of the most interesting aspects of zealotry Haggard explores is the subsequent social chaos that ensues. For example, when Owen's preaching stirs up the tribe, Hokosa and other witch-doctors,

were frightened for their place and power, and fomented it both openly and in secret. Of the women they asked what would become of them when men were 
allowed to take but one wife? Of the heads of kraals, how they would grow wealthy when their daughters ceased to be worth cattle? Of the councillors and generals, how the land could be protected from its foes when they were commanded to lay down the spear? Of the soldiers, whose only trade was war, how it would please them to till the fields like girls? Dismay took hold of the nation, and although they were much loved, there was open talk of killing or driving away the king and Nodwengo who favoured the white man, and of setting up Hafela in their place. (121)

When Christian missionaries appear, societal breakdown occurs within the tribe. Traditions are challenged and long held beliefs are tossed aside for a new god. Hokosa and the wizards encourage fear on all levels: with women, they stoke the fear of unmarried poverty; with rich men, they appeal to their greed by noting their daughters could not be sold for cattle anymore; with ruling advisors and military leaders, they foster fear of invasion if they cease to have an army; with warriors, they instil the fear of femininity due to lack of fighting. Soon, the Amasukans are possessed by fear of their future and consider killing their king in order to preserve their familiar ways. In fact, Owen reluctantly adapts Christianity to allow current polygamy: "Owen, having only the Scriptures to consult, came to a compromise with his converts. If a man already married to more than one wife wished to become a Christian, he permitted him to do so upon the condition that he took no more wives; while a man unmarried at the time of his conversion might take one wife only. This decree, liberal as it was, caused great dissatisfaction among both men and women" (146-7). Owen compromises a small aspect of Christianity to allow for native customs. Although this compromise was only temporary and applicable for a generation, Owen demonstrates sympathy and understanding for their traditions in a way that characters like John Dove or Basil Bastin never would. The novel's initial conflict between two brothers (Hafela and Nodwengo) 
morphs into a battle between the old and new religions, a battle which Nodwengo (and Christianity) wins at the price of their tribe's former customs. Haggard uses the Amasuka tribe to explore and depict tribal breakdown when Christianity is introduced. Although he leaves no doubt that Christianity is the "true faith," one cannot help noticing the destruction its introduction causes. This societal breakdown prepares the way for colonisation-with the Amasuka tribe committed to peace, the British would easily be able to claim their land. Thus, in a convoluted sense, Owen's divine mission to convert the Amasuka enables the Empire to fulfil its own divine mission of ruling over the world.

For Haggard, the zealot plays a necessary role in ushering the rebirth of society. By playing the "Messenger," Owen follows a divine mission that places him outside institutional support; neither the Church nor the Empire sanctions his mission, yet he follows the zeal which propels him to action. At the same time, Owen does not place himself entirely outside the Church; rather, his divine mission achieves what the Church is unwilling to try. The spiritual lethargy which drives Owen away from England is the same force which Haggard claims drives the best farmers from England. As spiritual and agricultural lethargy are intertwined, Haggard uses Owen to demonstrate the zealotry needed to shake the Empire into action. Zealots like Owen are crucial to Haggard's agrarian vision as their ardour can not only inspire people to return to farming and church, their actions can also provide additional lands for colonisation. As Haggard is concerned with the twin issues of spiritual and agricultural decline, his solution, as detailed in The Poor and the Land, combines both charitable and government organisations. Thus, the zealot plays an important role in instigating Haggard's philanthropic colonisation scheme. 


\section{John Dove: Renegade in the Wilderness}

Haggard uses the character of John Dove, from The Ghost Kings, to examine the ways in which a degenerating civilisation and religion inspires one to seek martyrdom. As a renegade character, John Dove's mission is to be martyred; he is seized by zeal to prove the genuineness of his faith, and he moves around England and then Africa condemning everyone's sins. Gerald Monsman describes the crucial role of the renegade character in empire fiction: "Their cultural relativism and theological dubiety led them toward a broad sympathy with figures that resist the values enshrined in the dominant, socially constructed ideals and practices of imperial culture. Thus the character of the renegade allows his author to mount a counter-cultural challenge without himself being tainted by association with turncoat actions or views" (Colonial Voices 211). Haggard uses John Dove to voice subversive thoughts on religion and Empire without sullying his own public image as a devout Christian and imperial servant. The role of the renegade is essential to Haggard's agrarian vision because it demonstrates the ineffectiveness of transplanting a legalistic form of Christianity to dominion lands. While in South Africa, Haggard was influenced by the controversial J. W. Colenso, Bishop of Natal, who advocated adapting Christianity to allow native practices such as polygamy. Although John Dove does not advocate such controversial practices (unlike Thomas Owen's temporary acceptance of polygamy), he does oppose the hypocrisy which pervaded the Church; John's zeal forces him to confront the sins which violate his legalistic faith. In this way, Haggard uses John as a renegade to expose the hypocrisy of the Church expelling one who legally follows the rules. The role of renegade is crucial to Haggard's vision for regenerating the Empire because it requires imperial institutions, including the Church, to examine whether or not they follow their own rules and mission. Just as Haggard's agricultural expertise allows him to critique imperial practices, 
John's theological proficiency allows him to critique the church from within: an act which ultimately banishes him from civilisation.

Although John's faith is similar to Owen's, the way in which it manifests reveals problematic motivation; unlike Owen, John's intent is purely selfish in that he wants above all to be a martyr. Therefore, although John successfully founded a mission, the focus on his motivations reveals the corruption of his faith. On the surface, John's mission is a typical imperial, Christian mission, yet Haggard places subversive descriptions that reveal this mission is unusual. From the very beginning, John Dove's "call" to preach to the natives is not sanctioned by the church. Dove was not a successful missionary. Neither the Dutch Boers nor their slaves appreciated his attempts to "Christianise" them (15). Unlike the narrator, John "lacked the sympathetic insight which would enable him to understand that a native with thousands of generations of savagery behind him is a different being from a highly educated Christian, and one who should be judged by another law" (15-6). This tongue-incheek passage shows how missionaries, without understanding of other cultures, tried to impose Christian morality onto natives. At the same time, John more strongly condemns the introduced white man's vices of "drink, theft and lying whereof before it had been innocent, he would openly condemn it to eternal punishment" (15). In John's worldview, the natives' vices are "childish, naive" in comparison to the more developed, civilised vices of white people, thus he more strongly damns the introduced vices.

John is an outsider in the structured church hierarchy and mission societies. His religious zeal alienates him from both white and native people. John is not representative of all missionaries. He is a pioneering zealot and unwilling to operate within the structure of organized colonisation. John "was too insubordinate, or, as he called it, too honest, to submit to the authority of his local superiors in the Church, and therefore would only work for his own hand" (16). His religious zeal propels him from England to South Africa and, finally, the 
land of the Zulus. John brings along his wife, Jane, and daughter, Rachel, even though his wife's second-sight foretells this journey will bring them death. The narrator suggests that John is obsessed with the idea of becoming a martyr. He goes to South Africa despite his wife's premonitions. John did not quail "personally from the prospect of martyrdom; this he could contemplate with complacency and even enthusiasm, but, zealot though he was, he did shrink from the thought that his beautiful and delicate wife might be called upon to share the glory of that crown" (Haggard 14). Haggard uses John's nebulous place as an outcast to place him as a renegade within the structures of Church and Empire. Although John supposedly spouts imperial theology, neither institution is comfortable with his caricatured attempts to reform them. At the same time, John would not find the physical martyrdom he seeks in England; thus he must leave for Africa to seek this destiny.

To further his ambition of martyrdom, John Dove builds a mission near the dangerous Zululand; natives from decimated tribes come to live near him or under him. They seek his protection, accept his charity, and listen to his preaching although it did not necessarily change them. John "preached to them day and night, most of them, it is true, did not understand much. Still they accepted them as the price of being allowed 'to live in his shadow,' but in the vast majority of cases they sturdily refused to put away" (165-6). Like his previous attempts, John fails to reach the natives or change their behaviour as he adheres to a legalistic interpretation of Christianity; however, the natives recognise John as a "good" man and accept his proselytising as the "price" for living safely. The natives are blessed by John's presence. He imports and teaches British agriculture techniques and improves their poor lives immensely. Life at the mission for the natives is described thus:

Indeed, never since Chaka broke upon them like a destroying demon had these poor folk been so happy. The missionary imported ploughs and taught them to improve their agriculture, so that ere long this rich, virgin soil brought forth 
abundantly. Their few cattle multiplied also in an amazing fashion, as did their families, and soon they were as prosperous as they had been in the good old days before they knew the Zulu assegai, especially as, to their amazement, the Shouter never took from them even a calf or a bundle of corn by way of tax.

The natives are happy for the first time since their various tribes were destroyed by the Zulu; they are also astounded that John Dove never takes a portion of their abundance as tax. This demonstrates an aspect of the Christian charity that motivates John's religious zeal. While most missions would exact a portion from the natives' crops, John is happy to "shout" at them. Thus, in a sense, John's legalistic faith is more pure than that of those who shun him, and this faith allows him to exercise such charity.

At the same time, John's ability to display such philanthropic generosity is indicative of his social and wealth status. During their years in Africa, "as he was well off, having inherited a moderate fortune in addition to what he had before he left England," John is tempted by his wife's pleading to return to England where he would be able to defend himself against the slander promulgated by the angry, unconverted Boers (17). After a night of "reflection and prayer," John rejects returning to England as "a specious temptation sent by Satan" (17). John argues "should he return to live in luxury in England not only unmartyred but a palpable failure, his mission quite unfulfilled?” (18). Moderately wealthy, John is rich enough to follow the fancy of martyrdom. He refuses to return to England because his zealot mission is not complete. He is compelled by an indescribable urge to complete this mission. John actively spreads Christianity and inadvertently promotes colonisation while operating outside the usual sanctioned imperialist efforts.

John attempts a condescending relationship with the natives - one of a superior condescending to bestow the gift of safety and agricultural prosperity to natives who in turn 
agree to accept his proselytizing. John's relationship with the natives is sustainable only when the natives agree to recognize his authority. The success of John's mission is due to both parties understanding and playing their respective roles: John as the "superior"morally, religiously, and educationally speaking — and the natives as "recipients," outwardly subservient, immoral, and ignorant. However, John's relationship with the natives is tenuous at best in that they outwardly listen to his preaching, yet "sturdily refuse to put away" their traditions, such as polygamy (166). Haggard's use of John offers an interesting picture of philanthropic colonisation - a renegade missionary whose zeal ostracizes him from British and colonial society eventually founds a successful mission near Zululand, through attracting fellow ostracized, downtrodden natives who pay minimal obeisance to his authority while maintaining their own beliefs and customs.

John, as a renegade missionary, allows Haggard to connect the hypocrisy of the Church to the degradation of the Empire. In Haggard's vision of Empire, the renegade character is useful in exposing the duplicity of people's actions in comparison to their imperial mission. John seeks martyrdom for his own glory, not for the sake of the Church or Empire which is why Owen's faith is portrayed as more pure. Haggard's agrarian rebirth of empire is tied to successfully refurbishing the national religion of Christianity; in order to cement the Empire's hold throughout the world, Christianity needed to become more malleable or adaptable to native customs. Haggard's public work as an agricultural reformer was at its peak during the period of The Ghost Kings (1908), and Haggard hoped that his scheme, while not as harsh as that of a renegade, would inspire the changes needed to restore the Empire. Just as John's theological knowledge allowed him to criticise fellow Christians' behaviour, Haggard's agricultural expertise enabled him to censure fellow imperial citizens. Thus, his use of renegade characters speaks to the revolutionary and confident attitude with which he promoted his agrarian vision of empire. 


\section{Basil Bastin: Reformer of Christian Missions}

Haggard uses Basil Bastin, from When the World Shook, to demonstrate the farcical yet noble nature of attempting a reformation through old and outdated methods. While Bastin reflects Haggard's fear that his scheme for imperial reform may be outdated, he is also a character whom Haggard imbues with pathos and nobility. Written during World War I, When the World Shook (1919) depicts a world in which modern civilisations may be destroyed because superhuman Oro determines they have not yet developed past barbaric wars. At the same time as writing the novel, Haggard struggles because his agrarian vision for redeeming the Empire is dashed aside and seems unable to fulfil the seemingly impossible task of reforming the Empire. Like Bastin's attempt to reform impressions of Christian missionaries, Haggard attempts to continue solving imperial issues through old schemes such as agricultural reform and population resettlement. For Haggard, the answer would always be returning people to the land - only through farming could the Empire be reborn. After all, the restoration of a moral people depends on returning them to farmland from which they draw goodness; however, his confidence in such a scheme weakens as he experiences a war which shakes the core of civilisation.

The contrast in personalities between Dove and Bastin is noteworthy in that the success of their proselytizing hinges on their ability, or inability, to connect with natives. To begin with, Haggard paints Bastin as a man of faith whose objective is simple and unwavering: spreading Christianity to all people. Much like the Salvationists whom Haggard admired, Bastin combines the best aspects of Christian piety with missional intentions. Arbuthnot describes Bastin as "an uncouth, shock-headed, flat-footed person of large, rugged frame and equally rugged honesty, with a mind almost incredibly simple....Yet he was good, so painfully good that one felt that without exertion to himself he had booked a first-class ticket straight to Heaven" (24-5). Bastin is a simple and good man; unlike Bickley's scientific 
inquiries, Bastin's faith is such that he never questions or is surprised by anything unnatural. Bastin's personality is such that he gets along well with most people "for although he thought that probably most things were sins, I never knew him to discover a sin which he considered to be beyond the reach of forgiveness. Bastin is indeed a most charitable man and in his way wide-minded" (31). Bastin is a forgiving man who considered everything sinful but was willing to forgive anything. Unlike John Dove, from The Ghost Kings, Bastin's “peculiarities, however, were easy to excuse and entirely swallowed up by the innate goodness of his nature which soon made him beloved of everyone in the place" (31).

Bastin is first inspired to become a missionary to the South Sea Islands after reading a publication which criticised a mission society to which he subscribes (66). After he, Bickley, and Arbuthnot are shipwrecked on Orofena, Bastin gets a chance to proselytize the Orofenans. The trio's first interaction with the Orofenans reveals Bastin's intentionsBickley and Arbuthnot arm themselves with pistols while Bastin is "fortified solely with a Bible" (106). Bastin asks the Orofenans, "Who is your God?" to which they reply, "Oro. He who fights" (114). Bastin replies, "I will give you a better one" (114). When the Orofenan chief, Marama asks, "What do you come to do?," Bickley replies, "We come to take that mountain (he meant lump) off your neck and make you beautiful; also to cure all the sickness among your people." Bastin adds, “And I come to give you new hearts” (116-7). Marama replies, "We do not want new hearts as the old ones are good, but we wish to be rid of lumps and sicknesses. If you can do this we will make you gods and worship you and give you many wives" (116-7). Bastin is not deterred by the Orofenans' lack of interest in a new god or religion, yet he is in a decidedly different position from that of John Dove who was able to parlay the African natives' lack of home and safety into a group of apathetic converts. John provided African natives with a safe home, new agricultural techniques, in addition to a new religion, while Bastin has none of these gifts to offer. 
Unlike John Dove who never allowed native religion to seep into his explanation of Christianity, Bastin finds success as a missionary when he gives "the name Oro to the Divinity" and admitted "that He might dwell in the mountain as well as everywhere else" (139). In fact, Bastin is so successful that Arbuthnot "perceived that the priests of Oro were beginning to grow very jealous of him and of his increasing authority with the people. Bastin was naturally triumphant, and even exclaimed exultingly that within a year he would have half of the population baptised" (139). Bastin's missionary zeal peaks in the chapter titled "Bastin Attempts the Martyr's Crown" when he decides to blow up the statue of Oro with paraffin. In retaliation, the priests tie up Bastin and prepare to burn him. Bickley and Arbuthnot arm themselves to rescue Bastin who they find "quite unmoved, smiling indeed, in a sort of seraphic way which irritated us both extremely" (158). Bastin says, "Thank you for coming ... though I don't think it is the least use. I cannot recall that any of the early martyrs were ever roasted and eaten, though, of course, throwing them into boiling oil or water was fairly common. I take it that the rite is sacrificial and even in a low sense, sacramental, not merely one of common cannibalism" (159). Arbuthnot and Bickley are annoyed by Bastin's placid acceptance of martyrdom, and his tepid response to their rescue. Bastin continues, "I do not know that I am really grateful. The martyr's crown was hanging above me, so to speak, and now it has vanished into the pit" (163). Bickley replies, "If you say much more, Bastin, I'll chuck you into the pit too, to look for your martyr's crown, for I think you have done enough mischief for one morning" (163). The result of Bastin's missionary zeal is the exile of the trio to the sacred island in the middle of the lake where the Orofenans would not dare to follow. Although both John Dove and Bastin accepted martyrdom as a fate worth having, their approaches differ in that Dove actively sought to be martyred and Bastin merely accepted martyrdom as a side effect of being a missionary. When the martyr's crown dangles above his head, Bastin is disappointed to not accept it in that moment, whereas Dove is 
possessed to seek a martyr's crown at the cost of his wife and daughter. Both John and Bastin's attitude towards martyrdom reveal a willingness to die for their faith; the difference in their attitudes stems from John's obsession with martyrdom superseding his faith whereas Bastin's faith overrules any desire for martyrdom. Bastin's attitude towards martyrdom connects to Haggard's faithfulness to the Empire; unlike John, Haggard does not seek to be martyred for his vision - rather like Bastin, he accepts martyrdom as a possibility for remaining faithful to a declining Empire .

Despite the evidence of his faith and the significant number of his converts, Bastin ultimately fails his mission to reform perceptions of Christian missionaries. Bastin's attempt to redeem Christian missions' image is farcical in that he tries to disprove critics using the same methods (i.e. destroying religious statues) for which they condemned missionaries. Bastin focuses on the wrong end of the criticism; instead of focusing on proselytizing, he should have focused on why England was producing spiritually weak missionaries at the beginning of the twentieth century. After all, to reform the image of Christian missions, one must look to the missionaries being sent as representatives. Similarly, Haggard's vision relies on spiritually vibrant people to spark a rebirth in civilisation; throughout Haggard's novels, powerful civilisations possess spiritually strong citizens. Thus, Haggard uses Bastin as a way to explore the tension between foolishness and nobility of attempting to reform an institution as complex as Christian missions or the Empire. For Haggard, the foolishness of his agrarian scheme is tempered by the nobility of his faith in restoring a civilisation deconstructed by the war.

\section{Conclusion}

In the movement amongst these three characters as zealot, renegade, and reformer, one can trace Haggard's evolving perception of Christian missionaries and the roles which they might 
play in restoring the Empire. Haggard's agrarian vision connects to the spiritual rebirth which he believes is necessary to rejuvenating a civilisation. Both Thomas Owen and John Dove are possessed by a fanatic zeal to proselytize unreached natives, although each represents a diverging motivation: Owen is a zealot motivated by a pure faith and a divine mission whereas John is a renegade motivated by a desire for glory as a martyr. Like Owen, Haggard is zealous for learning and sharing the truth of agricultural reform; he points to agricultural decline as the source of doubt in his imperial faith. Between writing The Wizard and The Ghost Kings, Haggard develops an agrarian scheme in The Poor and the Land to regenerate the Empire. Like John Dove, Haggard is a renegade, exploring the hypocrisy of imperial institutions. Both seek to uphold the ideals of the Church and Empire, yet are ostracised for exercising their faith. Haggard's agrarian vision saw him labelled a "socialist" for wanting to involve the government in social welfare issues like poverty and unemployment. While he defended himself from that label, he also unapologetically defended his resettlement scheme and travelled throughout the Empire speaking to whoever would listen. During World War I, Haggard's vision was overwhelmed by a sense of doom — suddenly, the agrarian solution seemed inadequate in the face of civilisation's decline. Like Bastin, Haggard seeks to reform the image of empire; however, unlike Bastin, Haggard recognises that his mission is futile unless a spiritual rejuvenation occurs. Haggard's role as a reformer shrinks his agrarian vision and, yet, he still has hope that people will eventually return to the land. Like all three characters, Haggard pursues an unsanctioned, divine mission which he hopes will not only restore the Empire, but will also turn people to a simple faith from which each civilisation draws its strength. 


\section{Chapter Three}

\section{The Role of Condescension in Interracial Friendship}

\section{Introduction}

Any attempt to categorise or identify Haggard's views on race is fraught with contradictions and generalisations as his personal views are riddled with inconsistencies. For instance, in the romance Benita (1906), Haggard created a villainous character named Jacob Meyer who is a poorly traced, Jewish caricature, whereas in Moon of Israel (1918), Haggard wrote a stirring and sympathetic portrayal of the Jewish people during the Exodus. As a man of his time, Haggard's novels operate on the assumed superiority of the white, British protagonists, yet this superiority is consistently subverted in unexpected ways. It is the stereotypical and racist depictions that critics such as Wendy Katz (Rider Haggard and the Fiction of Empire) and Anne McClintock (Imperial Leather: Race, Gender and Sexuality in the Colonial Contest) analysed to much acclaim. Among the first to apply literary theory to seriously analyse Haggard's novels, Katz and McClintock focused on imperialist themes through the lens of race and feminism; their criticism was instrumental in marking Haggard as relevant or important to scholarly discussions on imperial literature. Katz, in particular, paints Haggard as a racist.

In a chapter titled ““A Negro Excepted': Racism,” Katz argues that Haggard displays "very real racism. His fiction and nonfiction alike speak for themselves. Haggard's racism is transparently clear" (135). The root of Haggard's racism, and indeed that of his cohorts, lies in fear of the Empire's decline and losing control of the natives (132). Katz continues to say that "any idea of unity between black and white in Haggard's fiction is a unity of unequals" and proceeds to list character samples from Haggard's novels as evidence (135). She surmises that Haggard affected liberal views while unaware of his racist tendencies. Katz uses examples from many romances to build her argument that Haggard writes simplistic, 
African characters; the "lack of individuality" in these characters stems from Haggard's lack of "respect and intimacy" for African people (142). Katz cites extracts from Haggard's diary and letters as evidence of his "self-righteous and deluded racial thinking" (145). In the end, Katz labels Haggard an "imperial propagandist, a man who made use of every opportunity to advance matters related to Empire" (153).

Katz accurately identifies fear of the losing the Empire as a theme which haunts Haggard's novels, and she also persuasively argues that Haggard is unaware of his own racism. However, there are two major limitations to Katz's argument about the underlying racism of Haggard's works. First, Katz struggles to provide textual evidence to support the claim that Haggard was an "imperial propagandist." If one reads any number of Haggard's novels, one will find that characters more often encounter civilisations or tribes which undermine their imperial assumptions and often cast the Empire negatively. Additionally, Haggard's novels are an outgrowth of imperialism rather than a direct vehicle for the cause. Secondly, Katz oversimplifies her analysis of characters like Rachel Dove to support her argument of their racism thereby rendering it ineffective as it's easily proven otherwise. For instance, Katz claims Rachel Dove's racism extends to childhood when she only had "white and human" Boer children as companions (141); however, later in the novel, Rachel calls Noie, an African native, a "sister" and "friend," titles she never affixes to the Boer children.

Despite these limitations in her argument, Katz makes a compelling observation on the unease which characterises relations between white and black characters, an unease Haggard alludes to in both his fiction and nonfiction. This racial tension existed outside of Haggard's fictional worlds and using the genre of romance allowed him to explore ideas counter to imperial assumptions. With Katz and McClintock's decidedly critical views influencing subsequent scholars through the end of the twentieth century, it was not until Gerald Monsman published H. Rider Haggard on the Imperial Front: the Political \& Literary 
Contexts of His African Romances in 2006, that all of Haggard's African romances were properly assessed. Monsman's criticism diverged from Katz and McClintock in that he seeks to portray the nuanced and progressive approach Haggard used when depicting native characters. Monsman argues that Haggard's “intellectual accomplishment was to stand against nineteenth-century notions of historical inevitability, of impersonal laws that discounted human agency and its free choices" (236). In a chapter titled "Heretic in Disguise," Monsman describes Haggard as an "authentic heretic" who makes choices against the "socially constructed, regnant ideals and practices of his culture" (42). These choices included taking a native mistress as a young man in South Africa and supporting the continuance of polygamy among native converts (Pocock 28). Contrary to Katz, Monsman contends that Haggard "progressively and proactively" writes Zulu characters thereby "celebrating traditional Zulu values that had been destroyed, thus humanizing the Zulus and their history for the British public in the wake of the Zulu War" (43). Monsman's argument that Haggard humanizes rather than caricatures African natives_-particularly Zulusdiverges from Katz's perception of Haggard as a racist imperialist. Both Katz and Monsman land on the central theme of interracial relationships found in many of Haggard's romances. Although their theories contradict one another, a synthesis of their views (Katz's focus on inequality between white and black relationships and Monsman's emphasis on Haggard depicting other races humanely) yields an interesting framework through which to view Haggard's novels.

Building upon the work of both Katz and Monsman, I will argue in this chapter that Haggard's vision of a rebirth for the Empire is endangered by interracial friendships. If his scheme for resettling unemployed labourers or retired soldiers onto "empty" farmland is to be successful, Haggard must acknowledge the interracial tensions bound to meet these colonisers when they inhabit native land. Even more dangerous than potential fighting, 
though, is the possibility of friendship developing between the races. After all, friendship strips away the prescribed roles given to both coloniser and native, allowing for something more intimate to develop. Thus, any interaction between a white and black person was socially scripted-language borrowed from philanthropic condescension. It is the act of condescension that enables interaction between a coloniser and native; only when deviating from prescribed roles does friendship become a possibility. ${ }^{22}$ Through close analysis of interracial relationships in The Ghost Kings and The Wizard, one can see how the language of condescension facilitates the development of friendship.

\section{Condescension and Friendship}

The most complex and vibrant relationships featured in Haggard's novels are interracial pairings. From Rachel Dove and Noie in the Ghost Kings to Thomas Owen and Hokosa in The Wizard, these relationships defy modern stereotypes of Victorian racial sentiments. Haggard takes the familiar plot of "white man saving a native" and subverts that trope in unexpected ways. In both novels, a white woman and man develop friendships with African natives. Although the trajectory and details of these relationships differ, some interesting similarities appear when analysed through the lens of condescension. The condescension scene, as defined by Daniel Siegel, is one of a superior breaking a social barrier to dispense some sort of charity to an inferior recipient. The condescension scene operates successfully

\footnotetext{
${ }^{22}$ Although I will only focus on interracial friendship in this chapter, it is important to note Haggard's aversion to interracial romance. More specifically, the offspring of mixed couples. There are multiple interracial romances between characters, yet these romances usually end in death for the native. A few couples, as in Heart of the World or Montezuma's Daughter, are allowed to marry and have children, yet by the end of the novel, some disaster always kills the children. This aversion is shown in moments through the mixed race character, Noie, in The Ghost Kings. Mixed children represent a threat not only to the identity and "purity" of the Empire, but also to the survival of the tribe or civilisation from which their native parent comes.
} 
when the giver and recipient follow their assigned roles. However, the relationship and their respective roles are jeopardized when a closer bond, such as friendship, is formed. In Charity and Condescension, Siegel writes:

Help from a friend is distinct from the condescension of an authority figure, particularly because it is so routine. Part of the resentment produced by condescension comes from the fact that charity, by definition, can be withheld, and that anyone who pleads for help must anticipate (and provisionally accept) the humiliation of being refused. But when one friend asks another for help, there is no possibility of refusal, so that the asking never compromises the asker. (124)

Siegel describes the incompatibility of friendship and charity; closeness forges friendship and the colonisation aspect of philanthropy is endangered when a coloniser becomes friends with natives. Intentionally or not, Haggard uses these relationships to demonstrate the complexities of philanthropic colonisation efforts. Haggard creates lost civilisations and untamed tribes to challenge fictional, British colonisers. Relationships, such as friendship, undermine the success of colonisation and bring into question the assumed superiority of British values and religion.

There are three traditional, colonial roles that challenge or strain Haggard's fictional, interracial relationships: saviour vs. saved, master vs. servant, Christianity vs. native religion. The way in which these three roles intertwine plays a significant part in understanding and interpreting the difficulties of interracial relationships. Haggard's interracial friendships contain the following characteristics: the English, white person is a dual-citizen, born and inheriting the imperialist mind-set, yet more at home with natives in the African wilderness; the African native is high-born, represents the best of their race, and is an equal to the white person in terms of birth and status; in a moment of crisis, the white person condescends to 
save the African native's life; the moment after the crisis, the native offers their service and thus marks the beginning of their journey together; travelling and facing multiple dangers together creates an atmosphere where an intimate friendship develops; the story ends with the native dying heroically.

\section{Trajectory of Haggard's Interracial Friendships}

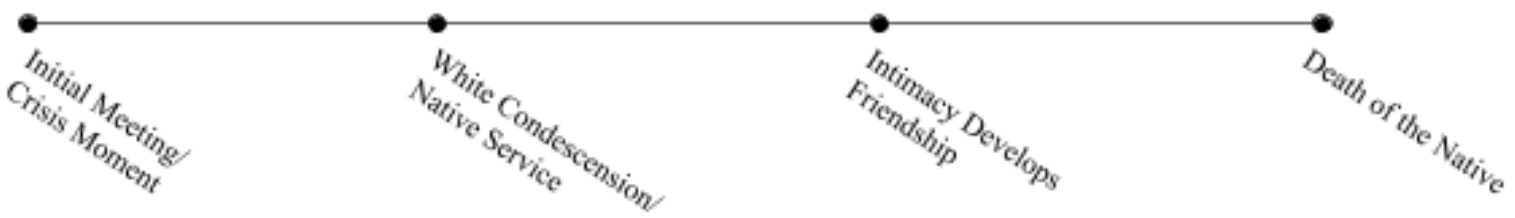

This is only a bare outline of Haggard's most common plot trajectory for interracial friendships; each novel contains specific details that differentiate the friendship, but in general, this summary holds true.

Perhaps the most famous example of this friendship belongs to Allan Quatermain and Umslopogaas — an interracial friendship which Haggard explores through two novels, Allan Quatermain (1887) and She and Allan (1921). Haggard first writes the conclusion of Quatermain and Umslopogaas' friendship in the novel, Allan Quatermain. Although their initial meeting is not described, it's clear from allusions that their previous adventures involved hunting, plotting, and wars. In their first encounter in Allan Quatermain, Quatermain unexpectedly meets Umslopogaas at the last outpost before his party embarks into unchartered territory. To re-establish their relationship after so many years, both assume the roles and language of their respective condescension roles. Umslopogaas greets Quatermain in Zulu fashion with “extravagant praising—-bongering' as they call it," and calls Quatermain "chief, "father," "my friend," and one "who grasps a hand and holds it to death (i.e. is a true friend)" (33). Umslopogaas' names for Quatermain decrease in levels of superiority until they are both on equal levels. In return, Quatermain interrupts Umslopogaas 
by saying he "had not seen him for twelve years," and that he "had warned" Umslopogaas against plotting to overthrow Cetywayo, the failure of which left him outcast from the Zulus (34-7). At the same time, he does not correct Umslopogaas' familiarity when called "friend." Umslopogaas allows Quatermain to play the role of superior by lavishing him with titles and praise; Quatermain accepts Umslopogaas' subservience and assumes a paternalistic tone in his greeting. In this case, condescension is the mode through which they recover their old friendship and intimacy.

Their friendship quickly resumes and an air of aged comrades replaces any formality between them. A final journey together "far into the unknown beyond" provides the perfect setting for the conclusion of their friendship (38). Encountering an "unknown" civilisation, like $\mathrm{Zu}-\mathrm{Vendis}$, together, creates an opportunity for these two social outcasts to break free from the racial and social codes of the Empire. However, even in $\mathrm{Zu}$-Vendis, Quatermain and Umslopogaas are separated by race. During a scene between two lovers, Quatermain leaves the pair to join Umslopogaas who does not think he will "ever learn to understand the ways of white people" as he thinks the lovers should just exchange cattle, be married, and be done with the business (392). The artifice of civilisation vexes both Umslopogaas and Quatermain in their desire to live as they please. It is due to these lovers not being able to follow his wise advice that heralds the death of both Umslopogaas and Quatermain.

To complete Haggard's trajectory of interracial friendships, the native dies to save his white friend. While preparing for the battle in which he dies, Umslopogaas says: "Listen, Macumazahn ... if those low fellows come, it is I who will hold the stair against them till the door is built up. Nay, nay, it will be a man's death: gainsay me not, old friend. It has been a good day, let it now be good night" (526). Again, calling Quatermain “old friend" indicates the length and closeness of their relationship, Umslopogaas will hold this strategic place, not only to save Quatermain, but also to gain glory in his final battle. Umslopogaas, gifted with 
native supernaturalism, tells Quatermain that he has dreamed of them "together on a star," looking "down on the world," and Quatermain was "as a spirit" (528). Although his vision does come true - first Umslopogaas and then Quatermain dies after the battle - the most interesting detail of his vision is that they are together after death. Death joins them in eternal friendship — a friendship that supersedes racial and social boundaries. In life, their friendship predicates upon both leaving their respective societies to have a successful relationship; after all, a friendship as intimate and powerful as theirs is a danger to both the Empire and the Zulu nation. Values, culture, and loyalties disintegrate when interracial friendships are allowed to flourish, and it is this fear which requires Haggard to end these relationships in death.

Another interracial pairing that appears to follow this trajectory yet deviates in unusual ways is the story of Thomas Owen and Hokosa in The Wizard. The initial crisis/meeting: Owen and Hokosa first meet at a feast where the king has ingested poison (supplied by Hokosa), and Owen, who retrieves the antidote due to a vision, saves the King's life. Owen reveals in private to Hokosa that he knows he supplied the poison to kill the king, but he will "pardon" Hokosa's sin. Hokosa is unwillingly indebted to him and agrees to "listen to your teaching," the price Owen sets for not revealing his secret (97.) The zealot Owen uses condescension to force Hokosa into listening to the Gospel message because Hokosa realises the price of his treason would be death. Hokosa's indebtedness and Owen's awareness of that debt deviates slightly from the trajectory in that usually the "saviour" tries to brush over or make light of the deed done to save the native. This deviation is important in developing Owen's character as "the Messenger," because most of Haggard's other protagonists possess a nebulous system of belief; whereas Owen is a devoted if not slightly mad Christian missionary. Unlike other interracial relationships, Owen expects Hokosa to repay his silence through religious conversion. These expectations prevent a true friendship from developing as Owen sets himself up as the "saviour" who represents the "Saviour." 
Equally important in distinguishing this relationship from others is the bitterness which motivates Hokosa to fatally poison Owen. Hokosa is "full of bitterness" that Owen has usurped his place as the chief "medicine man" and seeks his revenge through gifting poisoned fruit to Owen (186). Hokosa chafes under the condescension Owen bestows as being "contemptuously forgiven is almost more than he could bear" (186). Hokosa does not accept the role of a supplicant and he refuses to acknowledge Owen as a "saviour." After poisoning Owen, Hokosa begins to take an interest in Christianity. He asks many questions and ultimately chooses to convert. He repents of his actions and he accepts Owen's superiority, but it's too late-his death is required to atone for the sins of his people. Although he repents of his actions and assumes the correct attitude for a native condescended to by Owen, Hokosa's repentance does not restore the trajectory of Haggard's other interracial relationships. Owen and Hokosa's relationship never develops beyond their respective roles in condescension. First, Owen dies a martyr's death through poisoned fruit and then Hokosa dies a martyr's death crucified to a tree. Religion precludes a relationship more intimate than that of teacher and disciple. Perhaps Haggard demonstrates the strength of genuine-hearted missionaries - people who purely follow their faith which prevents them from lapsing into intimate personal relationships, interracial or otherwise. In any event, the relationship between Owen and Hokosa is less a friendship than a teacher mentoring his disciple. A distinction which marks it as significantly different from that of Rachel Dove and Noie in The Ghost Kings.

\section{Friends in the World of the Ghosts}

The relationship between Rachel Dove and Noie is the strongest and most active bond portrayed in The Ghost Kings. Rachel and Richard's romance is dim and simplistic in comparison to the complexities and emotions experienced in Rachel and Noie's friendship. 
Both Rachel and Noie struggle to define their relationship; what begins as a charitable act, morphs into voluntary servitude, and ultimately, supernatural sisterhood. ${ }^{23}$ While Rachel defines their relationship as "friends," Noie offers an alternative definition of "spirit sisters." The implication of "friendship" is one of equals while "spirit sisters" entails a supernatural bond with predestined roles. Their relationship first begins when Rachel and Ishmael, riding to the safety of the mission, encounter Noie being pursued by a Zulu warrior. Noie - the daughter of Seyapi, a dwarf-wizard from the Ghost people and an unnamed Zulu womanflees for her life because she refused to become Dingaan's concubine. Noie grasps Rachel's legs and begs, "Save me, white lady, save me!" (114). The moment of condescension between Rachel and Noie begins when Noie begs Rachel to save her life. Rachel responds to Noie's pleas and warns the warrior to leave or be shot dead. The warrior laughs at Rachel's threat and moves forward to kill Noie, so Rachel shoots and kills him. Ishmael is angry and terrified at the repercussions of this action and says, "My God! What have you done? Then your blood be on your own head. I am not going to stop here to have my throat cut," leaving Rachel and Noie to hide from the Zulus (118). After coming out of hiding, Rachel and Noie come across the bodies of Noie's massacred family. In grief, Noie kneels to commune with the spirit of her dead father. Noie identifies Rachel as Zoola and says, "Lady, from henceforth I am your servant, am I not? and that service will not be light" (132). Noie's appearance in the novel signals the beginning of Rachel stepping into the role of her supernatural, native goddess role. ${ }^{24}$ In this first scene, Rachel plays a "saviour" role for Noie; being saved from certain death, Noie accepts the role of Rachel's "servant" to repay the debt

\footnotetext{
${ }^{23}$ For a discussion on how charity enabled women to form sisterhoods, see Jill Rappoport's Giving Women: Alliance and Exchange in Victorian Culture (pp. 92-7).

${ }^{24}$ See Dorice Williams Elliott's description of a "philanthropic heroine" vs. a "traditional romantic heroine" (The Angel Out of the House 161).
} 
of living. Noie also hints at the supernatural, predestined nature of their relationship when declaring her role as a servant by identifying Rachel as the goddess, Zoola.

Like the narrator at the beginning of the book, Rachel seeks hidden, native knowledge by pressing Noie to divulge the words that Seyapi, Noie's dead father, whispered. Noie refuses to share and says, "Did I not tell you it was for my ear alone, O Inkosazana-y-Zoola? I dare not say it, be satisfied. But this I may say. Your fate and mine are intertwined; yours and mine and another's, for our spirits are sisters which have dwelt together in past days" (160). In Noie's view, as sister "spirits," both are compelled to play out their respective, predestined roles. Rachel condescendingly smiles "for she who had mixed with them from her childhood knew something of the mysticism of the natives, also that it was often nonsense" (160). Rachel replies, "Well, Noie, I love you, I know not why. Perhaps, for all you have suffered. Yet I say to you that if you wish to remain my sister in the spirit, you had better separate from me in the flesh. That jackal man [Ishmael] knows your secret, girl, and soon or late will loose the assegai on you" (160). Rachel makes no claim on Noie for the service of saving her life. Rachel encourages Noie to leave and flee for her life, but Noie refuses this offer as she believes her destiny lies at Rachel's side. In this moment of condescension, Rachel assumes the role of “superior” by dismissing Noie's witchcraft abilities and prediction.

As the story progresses, Rachel consistently refers to Noie as "friend" and "sister." To Noie, Rachel is the embodied spirit of Inkosazana-y-Zoola, a goddess whom Noie is destined to serve at the cost of her own life. Rachel and Noie's friendship defies clear definition, although both ascribe significant meaning to their relationship. Rachel tries to establish the friendship as one of equals. When Rachel brings Noie home, Noie agrees to go as her personal servant. Noie attempts to keep clear their role of "mistress and servant" while Rachel initiates a familiarity which blurs their roles. Throughout the novel, Rachel defends 
Noie and their friendship. When Rachel refuses Ishmael's marriage offer due to his multiple, native wives, Ishmael blames her refusal on "that accursed little witch, Noie" (183). Rachel replies, "Don't speak any ill of Noie, please; she is my friend" (183). Later, when held captive by Eddo, the priest and usurper of the Ghost people, Rachel speaks with Nya, Mother of the Trees, saying: "I know not how to travel it, who am alone in the world without a friend save Noie here" (606). Mother of the Trees replies, “'Not so. Thou hast another friend,' and she laid her hand upon Rachel's heart" (606). In this scene, Rachel is offered friendship by Nya, Mother of the Trees, a deposed, queen-priestess who is coincidentally Noie's aunt. Rachel relies on the protective friendship of Nya and Noie to survive. Rachel saves both Nya and Noie from death and in return, they give their lives to save hers.

Together, Rachel and Noie defy increasing levels of danger in their relationship, beginning with Ishmael, then Dingaan, and culminating with Eddo. Both Rachel and Noie inhabit two worlds yet belong in neither. They are in effect "ghosts." Noie says, "I am but half a Zulu" (155). Noie is half Zulu and half Ghost—she belongs to neither world. Her physical appearance and magical gifts alienate her from both groups: as a Zulu, the difference of her physical appearance catches the eye of Dingaan and unleashes the disaster of subsequent events, her magical, witchcraft abilities are feared; as a Ghost, she is disdained for being a half-breed and her witchcraft skills are mocked as substandard. Rachel also inhabits two worlds: British settler and English woman. Rachel is more at home in the wilderness of Africa than her childhood home in England. Rachel sees good in both savagery and civilisation, "For her, savagery had virtues as well as civilisation, although it is true of the latter she knew but little" (100). Although born in civilisation, Rachel does not fully inhabit that world. She has spent too much time trekking across South Africa to retain all the trappings of a civilised woman. Rachel cannot fully immerse herself in African life as inherited, imperial values prevent such degradation. Haggard emphasizes that Rachel "knew 
but little" of civilisation which undercuts her ability to assess either; in fact, Rachel understands "savagery" more than "civilisation," an important factor in Rachel's inability to keep to her role of "saviour/master." Their respective states allow a friendship to deepen beyond expectations - tied together by bonds of birth, circumstance, and supernatural forces, Noie and Rachel briefly inhabit a netherworld where their friendship is allowable. However, their friendship soon enacts its destructive conclusion with Noie repaying the debt of her life.

In the final act of the novel, Rachel and Noie experience a last adventure together in the spiritual realm. Seeking to discover if her lover is dead, Rachel convinces Nya, Mother of the Trees, to use her magic to project Rachel's spirit into the world of the dead. Noie asks to go with Rachel and so both consume a potion to seek the dead. However, while Rachel's journey takes her "beyond the stars," (524) Noie goes "down endless ladders into the centre of the earth" (525). While Rachel explores the heavens in search of her lover, Richard, Noie descends into the bowels of the earth to foresee how she will betray her people for love of Rachel. This imagery contributes to interpreting their friendship: Rachel's love for Richard draws her away from friendship while Noie's love for Rachel condemns her to treachery and death. Their friendship is unnatural — supernatural forces drew them together and in the end, supernatural elements draw them apart.

Noie's death is required for many reasons: she must be punished for burning the Tree of Life which is the Ghost people's life source; as half-Zulu, half-Ghost, Noie belongs to neither people and her existence threatens the continuity of both civilisations; she is indebted to Rachel for saving her life and in turn, must sacrifice her own to save Rachel; her friendship and indeed love for Rachel are unnatural, and cannot continue as they threaten to subjugate Rachel and Richard's colourless romance. As Noie nears her inevitable death, Rachel, oblivious to this, notes that "the loving, faithful Noie ... seemed half a thing of air" (510). Noie begins to fade into a ghost as she nears death. Noie is troubled by her eternal fate if she 
does burn the Tree and asks for a final word from her aunt, Nya. Noie will commit a "great sin" by killing her people, but the act is atoned through her love for Rachel. Nya also implies that Noie was predestined for this role and cannot struggle against fate by saying: "Thy heart is very bold, and thou also must follow it. Though thy sin should be great, perchance thy greater love may pay its price. At least thou art but an arrow set upon the string, and that which must be, will be" (573-4). Nya soothes Noie's conscience by pointing out that her choices and fate were predetermined by the goddess. To explain away illogical choices or inexplicable desires, Haggard turns to fatalism as the ultimate answer. Fatalism infuses Noie's choice with a tragic and supernatural burden; as a heroine, she cannot escape her fate to die for Rachel and to atone for the sins of her people.

Through Rachel and Noie's friendship, Haggard explores the societal dangers of interracial friendships as their relationship leads to the destruction of the Ghost civilisation. Noie sets the Tree on fire, heralding the destruction of the Ghost people. She is only half a Ghost and she has destroyed them for love of "sister" Rachel. Her role as a "ghost" is no more. She destroyed one of the worlds in which she could only partially dwell. She will no longer be a ghost in life, but a ghost in death. Noie says to Rachel,

Yet I have saved thee, my sister, I have saved thee and thy lover, for the Dwarfs are no more, the Grey People are grey ashes. For my love's sake I did the sin; let my love atone the sin if it may, or at the least think kindly of me through the long, happy years that are to come, and at the end of them then seek for lost Noie in the World of Ghosts if she may be found there. (597-8) For love, Noie destroys part of her heritage and asks Rachel to search for her in the afterlife. After Eddo drags Noie with him into the fire, the narrator notes, "Thus perished Noie, who, for love's sake, gave her life to save Rachel, as once Rachel had saved her" (600). The roles of condescension reverse with Noie replacing Rachel as the "saviour." Noie achieves equality 
in their relationship only after death, as in the "World of the Ghosts," both Rachel and she will be nothing more than ghosts.

Haggard's use of interracial friendships and this reoccurring plot trajectory reveals not only racist imperial sentiments, but also perceived dangers to the Empire's continuity. His focus on rebuilding or rebirthing the Empire conflicts with his respect and admiration for native peoples, such as the Zulus. Through his romances, Haggard explores the tension that exists within his psyche and the social constructs which support the Empire. Rules of interaction between the races borrowed heavily from condescension, and this language shaped how colonists and natives interacted throughout the nineteenth century. His fictional, interracial friendships utilise this language in the beginning to establish modes of authority which the white character can choose to subvert. When the white character chooses to subvert or undermine their own authority is when intimacy develops between the two; at the same time, the native character chooses to assume the role of inferior when seeking assistance. It is as though the natives are punished for seeking assistance as Haggard kills all native characters that develop too close a relationship with a white person. For Haggard, the dangers of interracial friendship are societal — a civilisation cannot succeed or be reborn if its citizens are friends with members of another. A civilisation can also be destroyed if one of its inhabitants loves the dweller of another, as in the case of Noie and the Ghost people. Since his land resettlement scheme relied on colonisers taking over native lands, the threat of interracial friendships jeopardised its success. As an imperial servant, Haggard yearned to serve and see his civilisation flourish. Beneath this servitude, Haggard also viewed the world through the cosmic lens of fatalism: civilisations rise and civilisations fall, a man can do all he can for the Empire, but if it is fated to end, then so it shall be. After all, for Haggard, everyone regardless of race can be reduced to a ghost. 


\section{Conclusion}

As the preceding chapters show, Haggard was very much concerned with perpetuating the British Empire. As an imperial servant, Haggard worked faithfully to uphold its virtues and ideals; however, Haggard also developed an agrarian vision which deviated from the modern trajectory of the Empire . Haggard looked to the past for answers, which placed him in an untenable position as both an imperial reformer and a modern renegade. Through the romance genre, Haggard expressed nostalgia for England's agrarian past; in real life, he identified agricultural decline as the source of imperial degeneration, and spent the rest of his life expounding the urgency to resettle unemployed labourers and ex-soldiers onto farmland. Although Haggard's resettlement scheme in The Land and the Poor was ultimately unheeded, it is, nevertheless, an important document which allows a fresh opportunity for interpreting his novels. Studying Haggard's fiction and nonfiction together allows one to trace the evolution of his views on the British Empire and the concept of civilisation.

This thesis provides a new way of interpreting Haggard's work through philanthropic colonisation — a lens which Haggard developed and refined between 1896 and 1919. While a great deal of Haggard scholarship centres around the ambiguities and contradictions found in his fictional, imperial representations, this thesis illustrates Haggard's clear vision for regenerating the Empire. Haggard used fiction to create the ideal people for his agrarian society, as well as to explore the internal (i.e. decline in morals and imperial virtues) and external (i.e. civilisations, natives, and interracial relationships) threats to its success. As previous literary criticism focuses on imperial connections, this thesis opens the possibility of broader discussions on topics such as the influence of World War I on Haggard's later novels, as well as the war's impact on Haggard's view of the British Empire . By focusing on novels written during Haggard's public service, this thesis reveals Haggard's growing 
disenchantment with the Empire 's modern trajectory. Haggard expressed a prophetic sense of joy when World War I dispelled the notion that society was post-violence and that the Empire was unnecessary. On 15 July, 1918, Haggard writes, "I thank God that I have lived to see the downfall of the Victorian idea and ideal .... Look whither this ideal has led us! Save for the Empire which they, or some of them, tried to stamp out, where should we be?" (Higgins, The Private Diaries 141-2). Haggard's depictions of violence were unpopular in the late 1890s-1914; many Victorians viewed Haggard's writing as "vulgar," and yet, during World War I, these "vulgar" descriptions were acceptable as patriotic expressions of valour (Higgins, The Private Diaries 142). Thus, while he firmly believed in the institution of Empire , Haggard desired and imagined regenerating the British Empire through an agrarian reformation. 


\section{$\underline{\text { Appendices }}$}

Explanation: As this thesis deals with lesser well-known novels by Haggard, I provide a summary of The Wizard, The Ghost Kings, and When the World Shook for reference. Each novel is listed in order of publication.

\section{The Wizard (1896)}

The Wizard follows protagonist, Rev. Thomas Owen, on his holy and solo mission to convert the Amasuka (People of Fire) tribe. The novel opens with Owen, possessor of a comfortable living in England, hosting a weary Deputation missionary from Africa whose sole purpose is to solicit funds for further missions. The worn-down missionary inspires Owen with his story of an unconverted tribe, the Amasuka or People of Fire, who kill the first English missionaries sent to convert them. Seized by a religious zeal or madness, Owen gives his living to the missionary and heads to Central Africa, convinced that God has called him to convert the Amasuka. Two years after arriving, Owen and his converted servant, John, are preparing to go preach salvation to the Amasuka. John, a native Amasukan, goes to the King Umsuka and asks for Owen to be given an opportunity to preach of the true God to his people. King Umsuka agrees for Owen, or "The Messenger" as he is known to the Amasuka, to preach about this god to his people if he is willing to prove through tests that his god is greater than their own. When Owen arrives, the royal family faces a coup by King Umsuka's eldest son, Hafela, and the chief wizard, Hokosa, poisoning the king because the king planned to pass his throne to his more virtuous son, Nodwengo. Through a divine dream the night before, Owen sees Hafela and Hokosa's plotting and was able to prepare an antidote to the poison, thus saving the king who gives Owen the highest place of honour as thanks for saving his life. 
At this point, the wizard, Hokosa, senses that his power and place are threatened by Owen whom he considers to be a mighty wizard. A series of Old Testament religious battles ensue between Owen and the Amasukan wizards. The chief battle occurs when Hokosa and his followers challenge Owen to stand on a plain prone to lightning strikes in the midst of a fierce storm. Followed by his servant John and newly converted Prince Nodwengo, Owen stands beneath a wooden cross as a show of faith that God will protect them. The storm spares the trio beneath the cross, yet the wizards are not so fortunate for the lightning strikes and splits their rock god, killing half their number and rendering Hokosa defeated. Hokosa's life is spared at Owen's request, and yet, Hokosa seeks revenge by giving Owen fruit laced with a slow-acting poison.

Meanwhile, King Umsuka dies and his two sons, Hafela and Nodwengo, begin a civil war over the throne. As Hokosa observes Owen's kindness and forgivenesss, he listens curiously to the Gospel. Hokosa converts within days, but believes he cannot be forgiven for poisoning Owen. When Hokosa confesses his treachery, Owen responds with forgiveness and love. Owen ultimately dies, but foretells Hokosa's death to save the Amasuka people. During their battle for the throne, Hafela drives Nodwengo and his followers into a narrow canyon, and Hokosa attempts to negotiate a truce. Hafela grabs Hokosa and crucifies him on a tree. As he slowly dies, Hokosa shouts down advice and prophesies the victory of Nodwengo. The novel ends with Hokosa dying on a tree shaped like a cross - lifted high above the converted and victorious Amasukans.

\section{The Ghost Kings (1908)}

This story centres on Rachel Dove, a typical golden-haired, grey-eyed woman who possesses certain virtues of civilized England, but also has access to the "native mind-set" as she has grown up in Africa. Rachel is more at home in the wilderness of Africa than her 
childhood home in England. Rachel sees good in both savagery and civilisation: "For her, savagery had virtues as well as civilisation, although it is true of the latter she knew but little" (100). Rachel's father, John Dove, is a renegade missionary who pushes his family further and further into the wilderness, driven by a zeal for martyrdom.

During a tremendous storm and flash flood, a teenaged Rachel encounters Richard Darrien, the son of a former naval officer turned hunter/trader. The two survive a night in an island cave where the threat of death by hungry lions and drowning fosters an immediate bond of closeness. The two share a brief kiss before Rachel's father and servants find them. Richard turns out to be the son of a former acquaintance of John's. Richard leaves Rachel to rejoin his father, yet Rachel has a dream that she will meet Richard again someday. Stories of her surviving the storm circulate among the natives and they bestow the name Inkosazana-yZoola ("Chieftainess or Lady of Heaven") on Rachel. The title carries supernatural connotations of a "white goddess" whom the natives believe is physically incarnated in Rachel.

The novel next picks up when Rachel is in her mid-twenties. John Dove brings his family to the border of Zulu country because he believes converting this tribe and Dingaan, their chief, to be his ultimate aim. Jane, his wife, is physically weak and Rachel beseeches her father to stop and build a home instead of going further into Zulu territory. Jane, who has the Scottish "second-sight," recognizes the edenic place where they stop from her dreams; she tells Rachel, "What was the dream now? Rachel weeping-Rachel weeping-my love, I think that we are going to live here, and I think_-I think___" (90). Rachel interrupts, "All right ... I don't mind I'm sure. I don't want to go to Zululand, and see this horrid Dingaan, who is always killing people, and I am quite sure that father would never convert him, the wicked monster" (90-1). Interrupting this scene is the appearance of a white man dressed in zebra skin pants who calls himself Mr. Ishmael. Rachel has an immediate aversion towards 
Mr. Ishmael and deliberately avoids time alone with him. Ishmael plays the role of a minor villain by obsessively seeking to marry Rachel. In the meanwhile, John Dove builds a mission and succeeds in attracting natives whose tribes were decimated by the Zulus.

One day while riding, Rachel meets and saves Noie, daughter of wizard Seyapi, who is fleeing for her life after refusing to become Dingaan's concubine. Noie serves Rachel as Zoola, and the rest of the story proceeds to show how their destinies are intertwined. Events quickly escalate with Dingaan, king of the Zulus, summoning Rachel to come give him counsel on whether or not to make war on the Boers. When Rachel finally accepts her role as Zoola, supernaturally inexplicable events occur. Rachel's parents die through the inadvertent plotting of Ishmael, Dingaan learns that he will die and his tribe will be broken, and Ishmael is burned to death. Dingaan doubts Rachel's role as Zoola and summons the Ghost Kings, or priests, for counsel. In exchange for their magical insight, the Ghost rulers take Rachel to their homeland.

When Rachel arrives at the Ghost people's kingdom — a dwarf-people who live in and derive their life from trees - Rachel finds a civilisation in decay, rotten with an inhumane punishment, a coup, and greedy ambition. After fulfilling her role as Zoola finished, Rachel finds her heart's greatest desire: Richard being held captive by the Ghost rulers. In order to ensure their happy future together, Noie chooses to sacrifice not only her life, but her civilisation's existence. Noie burns the Tree of the Tribe - the source of life for the Ghost people - thus Richard and Rachel are the sole survivors at the end of the novel.

\section{When the World Shook (1919)}

When the World Shook follows the journey of protagonist and narrator, Humphrey Arbuthnot, an attractive, educated, and moderately wealthy man who wearies of the finance industry and retires to a quiet country life. He entices university friends, Basil Bastin, a vicar, 
and J.R. Bickley, a surgeon, to set up practice near his home. Bastin and Bickley become close friends who disagree on everything - Bastin is a man of faith and Bickley is a man of science. Arbuthnot marries a beautiful woman named Natalie who, before dying in childbirth, tells him to "go where you seem called to go, far away. Oh! the wonderful place in which you will find me, not know that you have found me" (60). Seeking an adventure to distract him from memories of Natalie, Arbuthnot settles upon visiting the South Sea Islands with his best friends, Bastin and Bickley, and cocker spaniel, Tommy, as companions.

The trio sail from England to Samoa with various stops in between, yet the adventure truly begins when they embark from Samoa to Hawaii where they experience a terrible cyclone which shipwrecks them on an uncharted island called Orofena. Arbuthnot, Bastin, and Bickley claim to be gods to the natives surrounding them, although Bastin balks at this deception as it interferes with his missionary intentions. Bickley and Bastin set out to help both medicinally and spiritually the islanders, called Orofenans because they worship a god called Oro. After Bastin blows up the Orofenans' idol, the trio are forced to take refuge on a sacred island in the middle of a lake. They explore a cave and discover the remains of an advanced, ancient civilisation, the sole two survivors of which have been sleeping in crystal coffins for 250,000 years. Bickley manages to revive the god-like father and daughter pair called Oro and Yva. Oro claims to have destroyed most of humanity through a deluge and to have foreordained their reawakening when the world was ready for him to rule again.

While Bickley, Bastin, and Arbuthnot all eventually fall in love with the beautiful and kind Yva, Oro's dislike for all three men and modern civilisations grows. Through astral projection, Oro and Arbuthnot visit all the great, modern civilisations of the early twentieth century where Oro encounters horrifying scenes from World War I. After completing these visits, Oro decides that he must once again flood the world because modern civilisations are too savage to endure. In the meanwhile, Yva and Arbuthnot fall in love; Yva reveals that he 
is the reincarnated prince whom she once loved and that she is the reincarnated soul of his wife, Natalie. Before descending into the bowels of the earth, Oro offers Arbuthnot, Bickley, and Bastin places of prestige in his kingdom if they will help him once again flood the earth. When they refuse, Oro proceeds to shift the balance of the world. Before he succeeds, Yva steps in front of the laser light which causes her to disintegrate, thus saving the world from ruin. Devastated by her self-sacrifice, Oro turns to kill the trio but relents because of his fondness for Tommy, the dog. The trio escape from the depths of the earth, back to the surface of the island where the Orofenans beg them to leave. Thus, Bickley, Bastin, and Arbuthnot leave the island and eventually return home to England. Arbuthnot proceeds to write down their adventure while Bickley and Bastin continually debate whether Oro was a madman or telling the truth. Arbuthnot dies a year later from a head injury he sustained on the island, and Tommy, the dog, dies from a broken heart. 


\section{$\underline{\text { Works Cited }}$}

Addy, Shirley. Rider Haggard and Egypt. AL Publications, 1998.

“Ancient Relics." Northern Advocate, 14 February 1923. Papers Past. paperspast.natlib.govt.nz/newspapers/NA19230214.2.33. Accessed 20 Oct. 2016.

Boehmer, Elleke, editor. Empire Writing: an Anthology of Colonial Literature 1870-1918. Oxford UP, 1998.

Brantlinger, Patrick. Rules of Darkness: British Literature and Imperialism, 1830-1914. Cornell UP: 1988.

Burchardt, Jeremy. Paradise Lost: Rural Idyll and Social Change Since 1800. I.B. Tauris, 2002.

Chrisman, Laura. "The Imperial Unconscious? Representations of Imperial Discourse." Critical Quarterly. Vol. 32, no. 3, pp. 38-58, Sept. 1990. Wiley Online Library. doi:10.1111/j.1467-8705.1990.tb00605.x. Accessed 3 Nov. 2016.

---. Postcolonial Contraventions: Cultural Readings of Race, Imperialism and Transnationalism. Manchester UP, 2003.

---. Rereading the Imperial Romance: British Imperialism and South African Resistance in Haggard, Schreiner, and Plaatje. Oxford UP, 2000.

Cohen, Morton. Rider Haggard: His Life and Works. Hutchinson \& Co., 1960.

Conrad, Sebastian and Dominic Sachsenmaier. Competing Visions of World Order: Global Moments and Movements, 1880s-1930s. Palgrave Macmillan, 2007.

Elliott, Dorice Williams. The Angel Out of the House: Philanthropy and Gender in the Nineteenth-Century England. UP of Virginia, 2002.

Ellis, Peter Berresford. H. Rider Haggard: a Voice from the Infinite. Routledge \& Kegan Paul, 1978.

“The Empire Problem.” Ashburton Guardian, vol. XXXV, no. 8373, 14 February 1916. Papers Past. paperspast.natlib.govt.nz/newspapers/AG19160214.2.26.56. Accessed 20 Oct. 2016.

"Empire Trade Commission." The Colonist. Vol. LV, no. 13653, 19 February 1913. Papers Past. paperspast.natlib.govt.nz/newspapers/TC19130219.2.23.28. Accessed 20 Oct. 
2016.

Etherington, Norman. Rider Haggard. Twayne Publishers, 1984.

Field, John. Working Men's Bodies: Work Camps in Britain, 1880-1943. Manchester UP, 2013.

Gilbert Helen and Chris Tiffin, editors. Burden or Benefit? Imperial Benevolence and Its Legacies. Indiana UP, 2008.

Goodlad, Lauren. Victorian Literature and the Victorian State: Character and Governance in a Liberal Society. Johns Hopkins UP, 2003.

Gorman, Daniel. Imperial Citizenship: Empire and the Question of Belonging. Manchester UP, 2006.

Haggard, H.R. “Agriculture in Norfolk.” Times [London, England]. pg. 14, 8 Jan. 1895. The Times Digital Archive. Accessed 8 May 2017.

find.galegroup.com.helicon.vuw.ac.nz/ttda/infomark.do?\&source=gale\&prodId=TTD A\&userGroupName $=$ vuw \&tabID $=\mathrm{T} 003 \&$ docPage $=$ article $\&$ searchType $=$ AdvancedSe archForm\&docId=CS237820968\&type=multipage \& contentSet=LTO\&version=1.0.

---. Allan Quatermain. Dover Publications, 1951.

---. A Farmer's Year: Being His Commonplace Book for 1898. London, Longmans, Green, and Co., 1889.

---. The Ghost Kings. iBooks, ed., Cassell, 1908.

---. Heart of the World. London, Longmans, Green, and Co., 1895.

---. “The Land Question.” Times [London, England]. pg. 4, 28 Apr. 1886. The Times Digital Archive. Accessed 8 May 2017

find.galegroup.com.helicon.vuw.ac.nz/ttda/infomark.do?\&source=gale\&prodId=TTD

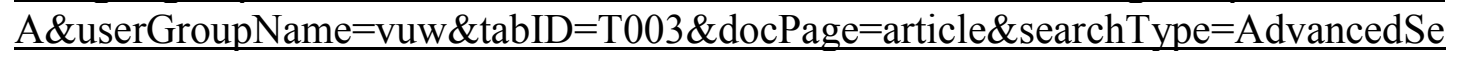
$\underline{\operatorname{archForm} \& d o c I d=C S 67291804 \& \text { type }=\text { multipage \&contentSet }=\text { LTO\&version }=1.0}$.

---. Montezuma's Daughter. London, Longmans, Green, and Co., 1893.

---. The Poor and the Land: Report on the Salvation Army Colonies in the United States and at Hadleigh, England, with Scheme of National Land Resettlement. Longmans, Green, and Co., 1905.

---. Regeneration: Being an Account of the Social Work of the Salvation Army in Great 
Britain. iBooks, ed., Longmans, Green, and Co., 1910.

---. Rural England. Longmans, Green, and Co., 1902.

---. She. iBooks, ed., London, Longmans, Green, and Co., 1886.

---. She and Allan. Hutchinson, 1921.

---. "Shrinkage of Population in Agricultural" (1899). Times [London, England]. pg. 3, 9 May 1899. The Times Digital Archive. Accessed 8 May 2017.

find.galegroup.com.helicon.vuw.ac.nz/ttda/infomark.do?\&source=gale\&prodId=TTD A\&userGroupName $=$ vuw\&tabID $=$ T003\&docPage $=$ article \&searchType $=$ AdvancedSe archForm \&docId $=$ CS50783401\&type $=$ multipage \&contentSet $=$ LTO\&version=1.0.

---. When the World Shook. iBooks, ed., Cassell, 1919.

---. The Wizard. iBooks, ed., Bristol, J.W. Arrowsmith, 1896.

Haggard, Lilias Rider. The Cloak That I Left. Hodder and Stoughton, 1951.

Hansan, John E. “Charity Organization Societies (1877-1893)." The Social Welfare History Project, 2013, socialwelfare.library.vcu.edu. Accessed 10 July 2016.

Hensley, Nathan K. Forms of Empire : The Poetics of Victorian Sovereignty. Oxford UP, 2016.

Higgins, D.S., editor. The Private Diaries of Sir H. Rider Haggard: 1914-1925. Stein and Day, 1980.

---. Rider Haggard: a Biography. Stein and Day, 1981.

Hultgren, Neil E. "Haggard Criticism since 1980: Imperial Romance Before and After the Postcolonial Turn.” Literature Compass, vol. 8, no. 9, 2 Sept. 2011, pp. 645-659. Wiley Online Library, doi:10.1111/j.1741-4113.2011.00827.x. Accessed 6 Sept. 2016.

Katz, Wendy. Rider Haggard and the Fiction of Empire : a Critical Study of British Imperial Fiction. Cambridge UP, 1987.

Liebfried, Philip. Rudyard Kipling and Sir Henry Rider Haggard on Screen, Stage Radio, and Television. McFarland, 2008.

Luckhurst, Roger. The Mummy's Curse: the True History of a Dark Fantasy. Oxford UP, 2012. 
Mabilat, Claire. Orientalism and Representations of Music in the Nineteenth-Century British Popular Arts. Routledge, 2008.

Manthorpe, Victoria. Children of the Empire : the Victorian Haggards. Victor Gollancz, 1996.

McClintock, Anne. Imperial Leather: Race, Gender and Sexuality in the Colonial Conquest. Routledge, 1995.

McClure, John A. Late Imperial Romance. Verso, 1994.

Miller, John. "The Environmental Politics and Aesthetics of Rider Haggard's King Solomon's Mines: Capital, Mourning and Desire." Victorian Writers and the Environment: Ecocritical Perspectives. Laurence W. Mazzeno and Ronald D. Morrison, editors. Routledge, 2017.

Monsman, Gerald. Colonial Voices: the Anglo-African High Romance of Empire. UP of the South, 2010.

---. H. Rider Haggard on the Imperial Frontier: the Political \& Literary Contexts of His African Romances. UP of North Carolina, 2006.

Murdoch, Norman. Origins of the Salvation Army. UP of Tennessee, 1994.

Murray, Tim. From Antiquarian to Archaeologist: the History and Philosophy of Archaeology. Pen \& Sword Archaeology, 2014.

O’Brien, Anne. Philanthropy and Settler Colonialism. Palgrave Macmillan, 2015.

O’Gorman, Francis, editor. Victorian Literature and Finance. Oxford UP, 2007.

"Philanthropic Colonization." San Francisco Call. Vol. 98, no. 43, 15 July 1905. California Digital Newspaper Collection. cdnc.ucr.edu/cgibin/cdnc? $\mathrm{a}=\mathrm{d} \& \mathrm{~d}=\mathrm{SFC} 19050713.2 .75$. Accessed 21 June 2016.

Pocock, Tom. Rider Haggard and the Lost Empire . Weidenfeld and Nicolson, 1993.

Poon, Angelia. Enacting Englishness in the Victorian Period: Colonialism and the Politics of Performance. Ashgate, 2008.

Rappoport, Jill. Giving Women: Alliance and Exchange in Victorian Culture. Oxford UP, 2012.

Reeve, Richard. "Henry Rider Haggard's Debt to Anthony Trollope: Dr Therne and Dr 
Thorne." Notes Queries. Vol. 63, no. 2, 2016, pp. 274-278.

doi:10.1093/notesj/gjw024. Accessed 26 Mar. 2017.

Senior, John. "Spirituality in the Fiction of Henry Rider Haggard." Dissertation, Rhodes University, 2003.

Showalter, Elaine. Sexual Anarchy: Gender and Culture at the Fin de Siècle. Virago, 1992.

"Sir Rider Haggard." The Times [London, England] No. 43962, p. 18, 15 May 1925. The Times Digital Archive. Accessed 4 Apr. 2017.

find.galegroup.com.helicon.vuw.ac.nz/ttda/infomark.do?\&source=gale\&prodId $=$ TTD $\underline{\text { A\&userGroupName }=\text { vuw } \& \text { tabID }=\mathrm{T} 003 \& \text { docPage }=\text { article } \& \text { searchType }=\& \text { doc } \mathrm{Id}=\mathrm{CS}}$ $\underline{302323887 \& \text { type }=\text { multipage } \& \text { contentSet }=\text { LTO\&version }=1.0 .}$.

“Sir Rider Haggard's Mission.” The Colonist. Vol. LVII, no. 14005, 8 February 1916. Papers Past. paperspast.natlib.govt.nz/newspapers/TC19160208.2.23.28. Accessed 20 Oct. 2016.

Siegel, Daniel. Charity and Condescension: Victorian Literature and the Dilemmas of Philanthropy. Ohio UP, 2012.

Stiebel, Lindy. Imagining Africa: Landscape in H. Rider Haggard's African Romances. Greenwood Press, 2001.

Watts, Michael. The Dissenters: Volume III: The Crisis and Conscience of Nonconformity. Oxford Press, 2015.

Zulli, Tania. Colonial Transitions. Internationaler Verlag der Wissenschaften, 2012.

ProQuest Ebook Central.

ebookcentral.proquest.com/lib/vuw/detail.action?docID=1056184. Accessed 21 Feb. 2017. 